\title{
INTEL, LEVERAGING REBATES AND THE GOALS OF ARTICLE 102 TFEU
}

\author{
Nicolas PETIT*
}

\begin{abstract}
This paper reviews the 2014 Intel judgment of the General Court of the EU in relation to exclusivity rebates given by dominant firms. It distinguishes between the positive issue - ie the legal standard currently applicable to the assessment of dominant firms' rebates - and the prospective discussion - ie the legal standard that should optimally apply to dominant firms' rebates. On the positive debate, the paper argues that Intel affirms a modified per se prohibition rule against dominant firms' exclusivity rebates. The scope of this standard is confined to leveraging rebates, and does not cover non-leveraging rebates, which must be analysed under the rule of reason. The paper also draws a distinction between exclusivity obligations and exclusivity options for which agencies and courts should undertake more economic analysis. On the prospective debate, the paper starts from the assumption made by several scholars that Intel endorses a non-welfarist view of the goals of Article 102 TFEU. With this background, it questions which non-welfarist alternative goal can be ascribed to Article 102 TFEU. The paper finds that none of the three classic nonwelfarist goals (ie competitive process, consumer choice and raising rivals' costs) can be acclimated in modern EU competition law.
\end{abstract}

\section{Keywords: antitrust, competition, abuse of dominance, exclusivity, rebates, law and economics.}

As anticipated, the judgment of the General Court ("GC") of the European Union ("EU") in Intel $v$ Commission (hereafter, "Intel") ${ }^{1}$ is generating intense discussion in antitrust journals. ${ }^{2}$ In itself, the profusion of essays on Intel is not a surprise. Given the high stakes involved in

Professor, University of Liege (ULg), Liege Competition and Innovation Institute ("LCII"). Nicolas.petit@ulg.ac.be. I am grateful to D. AUER, J-F. BELLIS, D. GERADIN, D. GERARD, E. GIPPINI FOURNIER, P. IBÁÑEZ COLOMO, L. IDOT, P. MARSDEN, J. MARCOS RAMOS and R. WHISH for their comments. I also wish to thank participants to seminars at the Belgian Competition Agency, at the Universities of Lund and Paris X Nanterre and at the 2015 AFEC annual conference in Paris. Those discussions helped shape my views on the Intel judgment. The opinions and ideas expressed in this paper remain mine only, unless otherwise acknowledged.

${ }^{1}$ Case T-286/09, Intel Corp. v European Commission [2014] not yet reported.

2 JS Venit, "Case T-286/09 Intel v Commission - The Judgment of the General Court: All Steps Backward and No Steps Forward" (2014) European Competition Journal August, 203-30; see also P Rey and JS Venit, "An Effects-Based Approach to Article 102: A Response to Wouter Wils" (2015) 38(1) World Competition 3-28. JS Venit (one of the lawyers who represented Intel during the proceedings) and P Rey argue that Intel introduces a per se prohibition standard for fidelity rebates. A similar view is defended by D Geradin, "Loyalty Rebates after Intel: Time for the European Court of Justice to Overrule Hoffmann-La Roche", (forthcoming) 11 (2005) Journal of Competition Law \& Economics. In contrast, P Nihoul places the debate on ideological grounds, reading in Intel a welcome repudiation of Chicago-school doctrine in single firm conduct cases. See P Nihoul, "The Ruling of the General Court in Intel: Towards the End of an Effect-based Approach in European Competition Law?" (2014) 5(8) Journal of European Competition Law \& Practice 521-30. Finally, another camp rejects such interpretations as off the wall. Professor Whish recalls that the strict prohibition has long existed in the case-law (arguably) for good reason. See R Whish, "Intel v Commission: Keep Calm and Carry On!" (2014) Journal of European Competition Law \& Practice, p. 2, who argues that the main problematic aspect of Intel is the rejection of a de minimis (or appreciability) rule in single firm conduct cases. See also, Pablo Ibáñez, who contends that the per se prohibition rule of fidelity rebates is historically based on an assumption of anticompetitive intent, which virtually disqualifies the need for any effects-based analysis in the field. See P Ibáñez Colomo, "Intel and Article 102 TFEU Case Law: Making Sense of a Perpetual Controversy", LSE Law, Society and Economy Working Papers 29/2014. Like Whish, he laments the inconsistency introduced by the Intel court with the idea that non-appreciable abuses can be deemed unlawful. 
abuse of dominance cases, this area of the law is kept under close watch by the antitrust industry. ${ }^{3}$ For right or wrong, every decision, judgment or policy statement related to the application Article 102 of the Treaty on the Functioning of the EU ("TFEU") is expected to be the game changer. In the debate, the law of abusive rebates has been particularly controversial for rebates constitute a widespread business practice with ambiguous anticompetitive effects. ${ }^{4}$

The early literature on Intel however displays two original features. First, some of the Intel papers have taken on a somewhat emotional tone, which is uncommon in EU scholarship. Second, and more importantly, the EU Commission - the EU body in charge of enforcing Article 102 TFEU and of defining abuse of dominance policy - is not united on the reading of Intel. In a recent paper, the Hearing Officer Wouter WILS has "commended" the Intel court for its judgment. On the other hand, Luc PEEPERKORN, a senior policy analyst with the Commission has written that the Intel judgment is "wrong". 5 Though not entirely unprecedented in the history of EU competition policy, the fact that the Commission does not speak in unison in the public arena is a rare, noteworthy feature.

Deep down in the raging doctrinal debate, lie two separate but often embroiled issues. On the one hand, a positive law discussion has taken place over the legal standard that does govern the assessment of fidelity rebates under Article 102 TFEU after Intel. This discussion focuses on whether the Commission's "more economic", effects-based approach articulated in the 2009 Guidance Paper on enforcement Priorities in Applying Article 82 of the EC Treaty to Abusive Exclusionary Conduct by Dominant Undertakings ("Guidance Paper") is good law, ${ }^{6}$ or whether the per se prohibition rule set over 30 years ago in Hoffmann-La Roche is the applicable standard. ${ }^{7}$ On the other hand, there is a prospective debate over the legal standard that should govern the assessment of fidelity rebates, and more generally of exclusionary pricing and non-pricing conduct under Article 102 TFEU. In the ideal antitrust world, the optimal test of abuse should minimise both type II (false acquittals) and type I (false convictions) errors, as well as enforcement (agency) and compliance (firm) costs. ${ }^{8}$

\footnotetext{
${ }^{3}$ R.B. REICH, “The Antitrust Industry”(1980) 68 Georgetown Law Journal 1053.

${ }^{4}$ M. A. EDWARDS, "The Law, Marketing and Behavioral Economics of Consumer Rebates", (2007) Vol 12:2, Stanford Journal of Law, Business \& Finance, 362: "During the past two decades, consumer rebates have become a major marketing method. Although exact figures are difficult to ascertain, estimates of total rebate offer volume now range from $\$ 4$ to $\$ 10$ billion per year. According to oneconsulting firm, over $80 \%$ of consumers participated in rebate offers in 2004, redeeming over five billion rebates worth more than $\$ 3$ billion. The prevalence of rebates within the consumer electronics and high-tech products markets is particularly pronounced-one recent industry study indicated that $25 \%$ of all computer hardware product purchases, and almost 50\% of personal computer sales included rebate offers". For a full account of the debate on rebates, as well as references, see R. O'DONOGHUE and J. PADILLA, The Law and Economics of Article 102 TFEU, Hart Publishing, 2013, Chapter 9.

${ }^{5}$ W. P.J. WILS, "The Judgment of the EU General Court in Intel and the So- Called 'More Economic Approach' to Abuse of Dominance" World Competition: Law and Economics Review, Vol. 37, No. 4, 2014, and contrast with L. PEEPERKORN, "Conditional pricing: Why the General Court is wrong in Intel (and what the Court of Justice can do to rebalance the assessment of rebates)", Concurrences No 1-2015 - Doctrines, forthcoming.

${ }^{6}$ Guidance Communication on the Commission's enforcement Priorities in Applying Article 82 of the EC Treaty to Abusive Exclusionary Conduct by Dominant Undertakings, OJ C 45 2009, pp 7-20.

${ }^{7}$ Case 85/76 Hoffmann-La Roche v Commission [1979] ECR 461. For a full account of the Guidance Paper and its context, see N. PETIT, "From Formalism to Effects? The Commission's Communication on Enforcement Priorities in Applying Article 82 EC", (2002) 32 World Competition, 485.

${ }^{8}$ WILS, supra note 5 discusses enforcement costs.
} 
Both the positive and the prospective law discussions are distinct, and should not be confused. This essay thus disentangles those issues, and reviews them in turn. On the first one, it conveys the argument that Intel retracts from, but does not entirely nullify, the "more economic" framework set out by the 2009 Guidance Paper, in particular for the assessment of rebates under Article 102 TFEU. It argues that it is wrong to consider that Intel restates (or resets) the test adumbrated in Hoffmann-La Roche for fidelity rebates. The wording of Intel delineates a more sophisticated regime, which consists in subjecting "leveraging" rebates including de jure or de facto "fidelity" or "exclusivity" rebates - to a modified per se prohibition rule, and all other types of rebates to the rule of reason. In short, the post-Intel test is a half-way between Hoffmann-La Roche and the Guidance Paper.

On the second issue, this essay does not side for one particular standard. Instead, it explores the Intel court's proposition that the goal of Article 102 TFEU is to ensure the protection of "rivals' access to the market" and of the "freedom of choice" of buyers. Some early discussants have discerned in those statements a blanket repudiation of the "outcome" paradigm as a goal of Article 102 TFEU (also known as the "welfarist", "output" or "efficiency" paradigm). 9 The reader will recall that the "outcome" paradigm was a salient feature of the 2009 Guidance Paper, where the Commission levelled concern at conduct giving rise to "consumer harm". If this interpretation is correct, a void remains to be filled in the goal(s) assigned to Article 102 TFEU. A non-outcome paradigm ought to be selected and explicated, if only to ensure a minimal level of clarity, generality, stability and prospectivity in decision making (without which there is no rule of law). ${ }^{10}$ The antitrust literature traditionally advances three possible alternatives to the "outcome" paradigm, ie the protection of the competitive process, of consumer choice, and raising the rivals' costs theory. This essay considers whether those alternative standards can be acclimated in the EU antitrust system.

The structure of this essay is as follows. It first recounts the evolution of EU competition policy in relation to rebates, up until the adoption of Intel (I). Readers familiar with the history of Article 102 TFEU law can directly head to Section II. It then argues that the positive standard affirmed by the Intel Court is "effects-based" friendly. At paragraphs 92 and 93, the judgment explicitly affirms an economic theory of harm as a basis for Article 102 TFEU liability, namely that dominant firms' rebates ought to be scrutinized if they generate a "leveraging" effect. However, the Intel court reclined on accepting all the operational consequences of this, by adding disconcertingly that the Commission should not scrutinize the economic context of dominant firms' rebates (II). Finally, the paper contends that it would help all stakeholders, and in the first place the Commission, the national competition agencies, the General Court and the national courts - who are in the driving seat of competition enforcement - to benefit from a clear dicta of the Court of Justice of the EU ("CJEU") on the rationale underpinning the Article 102 TFEU prohibition, in so far as exclusionary conduct is concerned. The Court already sought to advance on this complex journey in Post Danmark which, despite the many questions it raised, market a great improvement in terms of judicial clarity and literacy. Future cases - and in particular the pending appeal of the GC Intel judgment before the CJEU - offer a welcome opportunity to settle once and for all the current purposivist controversy, or whatever other label is used. This essay advances some ideas to that end (III).

\footnotetext{
${ }^{9} I d$.

${ }^{10}$ Lon L. FULLER, The Morality of Law. New Haven: Yale University Press, 1964; Gillian K. HADFIELD and Barry R. WEINGAST, "Microfoundations of the Rule of Law", Annu. Rev. Polit. Sci. 2014. 17:21-42.
} 


\section{A. INTEL IN CONTEXT}

\section{THE INTEL JUDGMENT}

In 2009, the Commission found Intel Corp. ("Intel"), a leading US manufacturer of central processing units ("CPUs"), guilty of abuse of dominance. ${ }^{11}$ The Commission inflicted on Intel a $€ 1,06$ billion fine, the highest penalty ever imposed in Europe in a single firm conduct cases. The Commission's theory of harm was that Intel had offered financial incentives to customers with a view to defeat the rapid expansion of its main rival AMD in the market for x86 CPU microprocessors ("x86 CPUs"). In the early 2000s, AMD had started to roll out a new suite of CPUs running at speeds in excess of $1 \mathrm{GHz}$ and based on a drastically novel design, the 64 bit architecture. AMDs' new CPUs directly threatened Intel's market leadership. Stuck in a process of Moore's law incremental innovation, Intel retaliated on the money front, granting rebates to computer manufacturers ("OEMs") such as Dell, HP, Lenovo and NEC on the condition that they would purchase all or almost all of their x86 CPUs from Intel. Intel also awarded payments to a large retailer, MSH in exchange for MSH selling exclusively computers containing Intel's x 86 CPUs. ${ }^{12}$

The Commission considered the rebates granted to the OEMs and MSH to be "de facto conditional". By "de facto" conditionality, the Commission meant that there was not a clear contractual exclusivity provision, but that under the contracts, Intel's customers entertained financial advantages in exchange for purchasing all or most of their CPU requirements with Intel. Paragraph 201 of the Commission's decision offers a graphic description of those contractual incentives:

"Dell negotiated with Intel that a small portion of the MCP discount could vary based on Dell's success in meeting specific criteria negotiated on a quarterly basis. This portion of the MCP discount was known as [...]MCP ('[...]'), and related to [...] of Dell's total spend (...) It could potentially fall to [...] or rise to [...] depending on Dell's performance against the negotiated criteria (emphasis added)". ${ }^{13}$

The Commission held that absent any objective justification, such rebates were abusive. ${ }^{14}$ It additionally conducted a 151 pages comprehensive economic analysis of the anticompetitive impact of Intel's rebates. Early commentators interpreted this analysis as a first practical try at what would later be labelled the "more economic" approach to Article 102 TFEU enshrined in the 2009 Guidance Paper. ${ }^{15}$

Intel appealed the Commission's decision before the General Court. Its pleadings focused on two legal points that are summarized at paragraph 70 of the judgment. First, Intel argued that in rebates cases, the Commission should have reviewed "all the surrounding circumstances" of the case to find competitive harm. ${ }^{16}$ With this, Intel sought to secure the Court's backing

\footnotetext{
${ }^{11}$ Commission Decision of 13 May 2009, Case COMP/37.990 Intel COMP/C-3/37.990 - Intel.

${ }^{12}$ In addition, Intel awarded HP, Acer and Lenovo, payments conditional on these OEMs postponing or cancelling the launch of AMD products and/or putting restrictions on the distribution of those products (socalled "naked restraints"). Our essay does not review those practices and their legal regime.

${ }^{13}$ Intel decision, supra note 11 at paragraph 201.

${ }^{14}$ Intel decision, supra note 11, at paragraph 925.

${ }^{15}$ R. O'DONOGHUE and J. PADILLA, supra note 4.

${ }^{16}$ Intel judgment, supra note 1, at paragraph 70.
} 
that the Commission had a duty to perform an economic assessment of the context and impact of the rebates, as a prior to challenging the factual foundations of the Commission's decision.

Second, Intel argued that where conduct is "historic", the agency should have reviewed available market data so as to verify allegations of anticompetitive foreclosure. On the facts, Intel claimed that the Commission had failed to scrutinize empirical market information. Devoid of this analysis, it decision had arguably not established that foreclosure had "actually" occurred in the market. ${ }^{17}$

The Intel Court disposed of both arguments. It first set that rebates "conditional on exclusive supply" or "on the customer's obtaining most of its requirements" constitute "exclusivity rebates". ${ }^{18}$ Recalling paragraph 90 of the 1979 Hoffmann-La Roche CJEU judgment, the General Court went on to state that such rebates "are designed to remove or restrict the purchaser's freedom to choose his sources of supply and to deny other producers access to the market". Accordingly, save an objective justification, "exclusivity rebates" are per se abusive, and there is no need to bring "proof of a capacity to restrict competition depending on the circumstances of the case". ${ }^{19}$ Intel's rebates fell squarely within this category, and the Commission was right to declare them unlawful. ${ }^{20}$

The General Court added that the Commission had no obligation to review the "surrounding circumstances" as advanced by the applicant. According to the Court, the test set in Michelin I and British Airways whereby the Commission must review "all the circumstances" of the case applies to "other rebate systems", i.e. rebates "where the grant of a financial incentive is not directly linked to a condition of exclusive or quasi-exclusive supply [...], but where the mechanism for granting the rebate may also have a fidelity-building effect ${ }^{21}$ To put it another way, where the rebate is not contingent on a specific purchasing behaviour on the part of the customer - for instance, it is linked to a sales target - "surrounding circumstances" matter.

Finally, the Intel Court logically disposed of the second argument of the applicant. Given the strict per se prohibition rule, effects do not matter in "exclusivity rebates" cases. ${ }^{22}$ Cases of "historic" exclusivity rebates thus do not deserve to be treated distinctly from cases of incipient, nascent or deficient conduct. The Commission was under no duty to carry out a concrete analysis of the actual effects of Intel's rebates in the market. With this, the General Court dismissed all of Intel's substantive grounds of appeal, and confirmed the Commission's decision in its entirety.

Besides the outcome of the case, an unprecedented feature of Intel is that it orderly delineates a typology of rebates under Article 102 TFEU. ${ }^{23}$ In the first category, "quantity rebates" are

\footnotetext{
${ }^{17}$ Intel judgment, supra note 1, at paragraph 70.

${ }^{18}$ In its pleadings, the Commission had called them "fidelity rebates within the meaning of the Hoffmann-La Roche case law". See Intel judgment, supra note 11, at paragraph 71.

${ }^{19}$ Intel judgment, supra note 1 , at paragraph 81.

${ }^{20}$ Interestingly, this analytical framework of analysis was also the Commission's one during the pleadings, rather than under the more economic test of the Guidance Paper as applied in the Intel decision

${ }^{21}$ Intel judgment, supra note 1, at paragraph 78.

${ }^{22}$ Intel judgment, supra note 1, at paragraphs 102-105.

${ }^{23}$ With this clear, and unconventional method of judicial discourse in appeals cases, the GC clarified the legal framework before the review of the factual arguments raised by the applicant. The Intel court should be praised for this. Many appeals judgments are close to unreadable, and the Intel judgment is an exception to this.
} 
"generally considered" not to yield the kind of foreclosure effect prohibited by Article 102 TFEU. They "reflect gains in efficiency and economies of scale" of the dominant firm, and are thus subject to a per se legality standard. ${ }^{24}$ A second category are "exclusivity" rebates linked to a condition of exclusive or quasi exclusive supply. Under the Hoffmann-La Roche precedent, those rebates are presumably unlawful, save in "exceptional circumstances". ${ }^{25}$ In its pleadings, the Commission had labelled them "fidelity rebates" (so had the Court in Hoffmann-La Roche). The Court refers instead to "exclusivity rebates", in a possible rhetorical attempt to emphasize their inherently problematic nature. The Court's pronouncements on this second category are those that have spurred scholarly debate. The third category comprises rebates that are "not directly linked to a condition of exclusive or quasi-exclusive supply", such as rebates conditioned on sales targets. They are subject to a rule of reason analysis. The Court says that it is necessary to "consider all the circumstances" surrounding those rebates. ${ }^{26}$

\section{INTEL'S PLACE IN THE CASE-LAW}

The Intel judgment has a number of fundamental legal features that can only be properly understood in context. As it stands, it is the latest application of a decades-old case-law precedent set in Hoffman-La Roche, where the Court affirmed a strict per se prohibition rule against "fidelity" rebates. This case-law emboldened the Commission. A boatload of dominant firms' rebates schemes were subsequently investigated, enjoined and litigated. This paved the way to the formation of a rich body of EU courts' precedents. In this section, we sift through this case-law.

In Michelin I, the dominant tire manufacturer Michelin had granted sales target rebates to dealers. ${ }^{27}$ The Commission and the Court considered this rebate scheme abusive. Both criticized the individualised, opaque and retroactive nature of Michelin's rebates. With such features, the impugned rebate scheme heightened the pressure on dealers to expand their purchases with Michelin, and in turn foreclosed rival tire manufacturers. Importantly, the Court suggested somewhat confusingly that the per se prohibition rule was not to be applied blindly noting that "It is necessary to consider all the circumstances, particularly the criteria and rules for the grant of the discount, and to investigate whether, in providing an advantage not based on any economic service justifying it, the discount tends to remove or restrict the buyers ' freedom to choose his sources of supply". ${ }^{28}$

$B P B$ was about a dominant producer of plaster boards, BG, who had offered to cover the promotional and advertising expenses of its customers, in exchange for exclusivity. ${ }^{29}$ Citing to Michelin I as precedent, the Commission and the Court found that BG had unlawfully given financial advantages in order to prevent its customers from dealing with rivals. This was, in and of itself, akin to unlawful abuse under Article 102 TFEU. ${ }^{30}$

\footnotetext{
${ }^{24}$ Intel judgment, supra note 1, at paragraph 75.

${ }^{25}$ Intel judgment, supra note 1, at paragraph 77.

${ }^{26}$ Intel judgment, supra note 1, at paragraph 78.

${ }^{27}$ Case 322/81, NV Nederlandsche Banden Industrie Michelin v Commission ('Michelin I') [1983] ECR 3461.

${ }^{28}$ Idem, at paragraph 14.

${ }^{29}$ Case T-65/89, BPB Industries Plc and British Gypsum Ltd v Commission, [1993] ECR II-00389.

${ }^{30} \mathrm{Idem}$, at paragraph 120.
} 
In Michelin II, ${ }^{31}$ Michelin had rolled out a system of "progress bonus" which awarded financial advantages to dealers that would increase tire purchases as compared to the previous year. ${ }^{32}$ Unlike in Michelin I, the impugned rebates were not individualised, but standardised. And there was no exclusivity requirement. This notwithstanding, the General Court considered that in view of their "loyalty inducing" nature, those rebates could be deemed abusive.

In British Airways, ${ }^{33}$ a dominant airline had awarded performance bonuses to travel agents. The Commission and the EU Courts found them abusive. The bonuses in question were retroactive and based on individualised and progressive sales targets. Given the "unavoidable business partner" position of British Airways, the bonuses generated a fidelity-building effect which prevented travel agents to buy tickets from rival airlines (such as Virgin Airways). ${ }^{34}$

Tomra was about agreements between a dominant producer of machines that collect used beverage containers and retail outlets (eg, supermarkets). ${ }^{35}$ The impugned contracts contained exclusivity and preferred supplier clauses, quantity commitments corresponding to de facto total or partial exclusivity, as well fidelity rebates subject to volume thresholds. The Commission found the agreements overall abusive. In relation to Tomra's rebates, the Commission carried out a price-cost analysis which elicited exclusionary effects. This constituted the first decisional application of the methodology formulated in the 2009 Guidance Paper. ${ }^{36}$ On appeal, the Court of Justice of the EU dispensed the Commission from such evidentiary hurdles. It maintained that a qualitative approach sufficed to establish abuse. $^{37}$ And like in Michelin I, the Court somewhat relaxed the Hoffmann-La Roche precedent noting that rebates had to be assessed in the light of "all the circumstances, particularly the criteria and rules governing the grant of the rebate". ${ }^{38}$ Lastly, Tomra is also the case that controversially stated that fidelity rebates are abusive regardless of their market coverage. ${ }^{39}$

Besides this long record of prohibition cases, the recent case-law also embodies occasional failures to prosecute dominant firms' rebates. In Velux ${ }^{40}$, the Commission abandoned an investigation against a dominant roof windows producer who had granted discounts to its distributors. Like in Tomra - of which Velux is contemporary - the Commission approached

\footnotetext{
${ }^{31}$ Case T-203/01, Manufacture française des pneumatiques Michelin v Commission, [2003] ECR II-04071.

${ }^{32}$ The case also concerned other types of rebates which are less relevant for the present discussion.

${ }^{33}$ Case T-219/99, British Airways plc v Commission, ECR [2003] II-05917; Case C-95/04 P, British Airways plc $v$ Commission, ECR [2007] I-2331.

${ }^{34}$ Case C-95/04 P, note 33 at paragraphs 71,73, 75.

${ }^{35}$ Case T-155/06, Tomra Systems ASA and Others v Commission [2010] ECR II-4361; Case C-549/10 P, Tomra Systems ASA and others v Commission [2012] ECLI:EU:C:2012:22.

${ }^{36}$ F. P. MAIER-RIGAUD and D. VAIGAUSKAITE, "Prokent/Tomra, a Textbook Case? Abuse of Dominance Under Perfect Information” (May 3, 2011), EC Competition Policy Newsletter, No. 2, pp. 19-24, Summer 2006.

${ }^{37}$ Case C-549/10 P, note 35 at paragraph 68.

${ }^{38}$ Case C-549/10 P, note 35 at paragraph 71.

${ }^{39}$ In other words, Tomra affirmed that there is no such thing as a de minimis abuse. This means that dominant firms cannot argue a defense whereby its rebates only affect a small fraction of demand. In the Court's view, rivals of the dominant firm must remain "able to compete on the merits for the entire market and not just for a part of it".

${ }^{40}$ Commission Decision, COMP/39.451 - Velux (closing of proceedings), See also, S. ALBAEK and A. CLAICI, "The Velux case — an in-depth look at rebates and more" (2009) 2 Competition Policy Newsletter. Available at: http://ec.europa.eu/competition/publications/cpn/2009_2_10.pdf (accessed 11 May 2015).
} 
the case with a price-cost analysis. This time, however, it reached the conclusion that the incremental rebates under scrutiny exerted no anticompetitive foreclosure effects. ${ }^{41}$

In Euronext, the Commission's initial concerns were that a dominant equity trading platform had introduced rebates on the original fee schedule applied to liquidity providers (brokers working for large investment banks) in response to the entry of the London Stock Exchange ("LSE") on the market. Little information filtered on this case. However, Commission officials reported that the investigation had been closed short of evidence that the investigated rebates were retroactive or that they were individually targeted. ${ }^{42}$

\section{SUMMATION}

Until Intel, the case-law on fidelity rebates exhibited two notable features. First, "fidelity" rebates were subject to a per se prohibition rule, with the somewhat confusing ambiguity introduced in Michelin I that "all the circumstances" were relevant in the assessment. On cursory analysis, Intel rationalizes the standard. Fidelity rebates are per se prohibited, period. The sole manifest modification brought by the judgment lies in the epithet. The GC substitutes the expression "fidelity rebates" with "exclusivity rebates".

The rationale behind this strict prohibition standard is discussed in the scholarship. ${ }^{43}$ Pablo IBANEEZ advances that the case-law deems fidelity rebates per se abusive because it considers that they are driven by anticompetitive intent. ${ }^{44}$ Hence the reason for a severe liability standard, and a light evidentiary regime. This reading finds comfort in the English version of paragraph 90 of Hoffmann-La Roche where it is written that such rebates "are designed to deprive the purchaser of or restrict his possible choices of sources of supply and to deny other producers access to the market (emphasis added)". It is also consistent with the line of caselaw that reputes exclusive dealing or other types of dominant firm conduct as abusive, absent an objective justification. ${ }^{45}$

Alberto HEIMLER has proposed a distinct interpretation. In his view, the Court presumptively posits that contractual (or non-contractual) exclusivity will generate exclusionary effects, though it is unclear on which economic theory of probability this reasoning is based. HEIMLER captured this with a telling metaphor, writing that the EU Courts' approach to fidelity rebates is akin to "banning the sale of Ferrari cars, because it is highly probable that drivers will not respect the speed limits". ${ }^{46}$

\footnotetext{
${ }^{41}$ Interestingly, the Commission applied its Guidance paper to reach this conclusion. See S. ALBAEK and A. CLAICI, "The Velux case — an in-depth look at rebates and more" (2009) 2 Competition Policy Newsletter. Available at: http://ec.europa.eu/competition/publications/cpn/2009_2_10.pdf (accessed 11 May 2015).

${ }^{42}$ Euronext had offered two rounds of price reductions in the form of temporary rebates for operations on Dutch securities. See S. GREENAWAY, “Competition between stock exchanges: findings from DG Competition's investigation into trading in Dutch equities" (2005) 3 Competition Policy Newsletter. Available at: http://ec.europa.eu/competition/publications/cpn/2005_3_69.pdf (accessed 11 May 2015).

${ }^{43}$ This approach has some merits. It ensures total legal certainty and nullifies enforcement costs. However, it also comes with a steep price, that of over-enforcement errors.

44 IBÁÑEZ COLOMO, "Intel and Article 102 TFEU Case Law: Making Sense of a Perpetual Controversy", supra note 2.

${ }^{45}$ Idem.

${ }^{46}$ A. HEIMLER, "Pricing below costs and loyalty discounts: are they restrictive and if so, when?" (2005) 1 Competition Policy International, 149.
} 
In our view, HEIMLER's reading is more convincing. The French speaking version of paragraph 90 of the Hoffmann-La Roche judgment clearly looks at a probabilistic effects standard, and not at an intent-one. It notes that fidelity rebates "tend to deprive the purchaser of, or restrict his possible choices of sources of supply and to deny other producers access to the market (emphasis added)". ${ }^{47}$

Admittedly, the French speaking version of Hoffmann-La Roche should not be given more relevance than the English one. But, as readers familiar from EU law know, French is the language in which the EU judges work and decide cases. It is thus an accepted custom in EU legal scholarship to give authority to the French-speaking versions of judgments, when linguistic inconsistencies arise. ${ }^{48}$ More importantly, this interpretation is the sole reconcilable with subsequent paragraphs of the Hoffmann-La Roche judgment, and in particular with paragraph 91. The Court defines there the notion of abuse in principled terms, and vindicates an effects-based standard: "the concept of abuse is an objective concept relating to the behaviour of an undertaking in a dominant position which ... has the effect of hindering the maintenance of the degree of competition still existing in the market or the growth of that competition (emphasis added)". ${ }^{49}$

A second lesson to draw from the pre-Intel case-law is that - with the possible exception of Velux - most fidelity rebates cases have been dealt with under a qualitative analytical framework. This can be observed at two levels. On the one hand, when exclusivity is not formulated as an explicit contractual condition for the rebate (de jure exclusivity), the Court has accepted that the agency establishes that the financial incentives granted by the dominant firm are de facto conducive to exclusivity, ie they induce the customer to purchase all or almost all its requirements from a dominant supplier. In the case-law, de facto exclusivity has often been established by looking at the design of the rebates systems. On this, Intel seems to set an even lower standard, retaining a sort of 'you know it when you see it' rule to characterize exclusivity. On the other hand, the case-law has paid little attention to the proof (or lack thereof) of actual or potential effects exclusionary effects. Here, Intel holds the line. The test of anticompetitive exclusion applicable to rebates cases, in particular those falling in the third category, remains largely abstract and vague.

\footnotetext{
${ }^{47}$ To make things clear, the writer of this essay is French-speaking by mother tongue.

${ }^{48}$ This is not a rare feature in the EU legal order

${ }^{49}$ Hoffmann-La Roche judgment, at note 7, paragraph 91.
} 


\begin{tabular}{|c|c|c|}
\hline Type of rebate & Test in Guidance Paper & Test in Intel \\
\hline Quantity rebate systems $(\$ 75)$ & Per se legality & $\begin{array}{c}\text { Per se legality (refers to } \\
\text { Michelin II) }\end{array}$ \\
\hline Fidelity "Exclusivity” rebates & $\begin{array}{c}\text { Rule of reason (implied } \\
\text { predation + objective } \\
\text { justification) }\end{array}$ & $\begin{array}{c}\text { Per se illegality (refers to } \\
\text { Hoffmann-La Roche) }\end{array}$ \\
\hline $\begin{array}{c}\text { Rebates not linked to a condition } \\
\text { of exclusive or quasi exclusive } \\
\text { supply (\$78) } \\
\text { targets }\end{array}$ & $\begin{array}{c}\text { Rule of reason (implied } \\
\text { predation + objective } \\
\text { justification) }\end{array}$ & $\begin{array}{c}\text { Rule of reason ("consider all the } \\
\text { circumstances" refers to } \\
\text { Michelin I) }\end{array}$ \\
\hline
\end{tabular}

\section{B. INTEL AND LEVERAGING REBATES}

A first reading of Intel invites the conclusion that the General Court perpetuated the per se prohibition rule of "fidelity" rebates set in Hoffmann-La Roche. This rendition is, however, both incomplete and incorrect. Intel brings two crucial modifications to the per se prohibition regime inherited from Hoffmann-La Roche. First, it clarifies that an economic theory of harm underpins the prohibition of dominant firms' rebates (A). This theory is the leveraging scenario that already appeared in several sections of the Guidance Paper, and especially in the section devoted to "conditional rebates". Those statements are not without consequences on the positive legal standard applicable to exclusivity rebates. They mean that the scope of the per se prohibition reaffirmed in Intel only covers a narrow subset of exclusivity rebates, ie leveraging rebates (B). Second, despite the fact that Intel had raised no efficiency defense in its appeal, the Intel Court ruled on its own motion, and with principled terms, that dominant firms' rebates can be redeemed by efficiency benefits $(\mathrm{C})$. The result of all this is that the positive legal standard applicable to fidelity rebates following Intel is not a strict per se prohibition rule, as aired in early scholarship, but a modified per se prohibition rule (D).

\section{INTEL AND THE ECONOMIC THEORY OF ANTICOMPETITIVE LEVERAGING}

It is not uncommon for the EU courts to explain the rationale underpinning key provisions of the Treaties. In the competition field, many judgments have explicated the basis for (in mundane terms the "why" of) antitrust liability. Airtours, on coordinated effects, ${ }^{50}$ Post Danmark on limit pricing, ${ }^{51}$ or Groupement des Cartes Bancaires on two-sided markets are cases in point. ${ }^{52}$

Intel is of the same craft. It marks an important evolution in relation to exclusivity rebates. Paragraphs 92-93 of the judgment make abundantly explicit that an economic theory of harm underscores the prohibition of exclusivity rebates. We reproduce in full those important and

\footnotetext{
${ }^{50}$ Case T-342/99 Airtours v Commission [2002] ECR II-2585.

${ }^{51}$ Case C-209/10 Post Danmark A/S v Konkurrencerådet [2012] ECLI:EU:C:2012:172.

${ }^{52}$ Case C-67/13 P Groupement des cartes bancaires (CB) v Commission [2014], ECLI:EU:C:2014:2204.
} 
often overlooked paragraphs:

\begin{abstract}
"It follows from the position of unavoidable trading partner that customers will in any event obtain part of their requirements from the undertaking in a dominant position ('the non-contestable share'). The competitor of an undertaking in a dominant position is not therefore in a position to compete for the full supply of a customer, but only for the portion of the demand exceeding the non-contestable share ('the contestable share'). The contestable share is thus the portion of a customer's requirements which can realistically be switched to a competitor of the undertaking in a dominant position in any given period, as the Commission states at recital 1009 of the contested decision. The grant of exclusivity rebates by an undertaking in a dominant position makes it more difficult for a competitor to supply its own goods to customers of that dominant undertaking. If a customer of the undertaking in a dominant position obtains supplies from a competitor by failing to comply with the exclusivity or quasi-exclusivity condition, it risks losing not only the rebates for the units that it switched to that competitor, but the entire exclusivity rebate.
\end{abstract}

In order to submit an attractive offer, it is not therefore sufficient for the competitor of an undertaking in a dominant position to offer attractive conditions for the units that that competitor can itself supply to the customer; it must also offer that customer compensation for the loss of the exclusivity rebate. In order to submit an attractive offer, the competitor must therefore apportion the rebate that the undertaking in a dominant position grants in respect of all or almost all of the customer's requirements, including the non-contestable share, to the contestable share alone. Thus, the grant of an exclusivity rebate by an unavoidable trading partner makes it structurally more difficult for a competitor to submit an offer at an attractive price and thus gain access to the market. The grant of exclusivity rebates enables the undertaking in a dominant position to use its economic power on the non-contestable share of the demand of the customer as leverage to secure also the contestable share, thus making access to the market more difficult for a competitor".

Anybody with antitrust background will recognize instantly and correctly in those paragraphs the classic theory of anticompetitive leveraging. The theory rests on the premise that in a market with a dominant firm, a share of the demand of each customer is inelastic. ${ }^{53}$ In other words, each customer reserves a fixed proportion of its requirements to the dominant firm. ${ }^{54}$ In principle, the dominant firm can charge the monopoly price on this inelastic share of customer demand. The Intel court talks of the "non-contestable" share of customer demand. But the dominant firm may prefer to strategically leverage the non-contestable share of customer demand towards the "contestable share" of customer demand, so as to exclude fringe rivals and subsequently apply the monopoly price on larger quantities. To that end, the dominant firm will offer discounts on the non-contestable share in exchange for supplementary purchases in the contestable share. With this, the dominant firm progressively devours the contestable share of demand on which fringe rivals compete. Conceptually, this theory - we call it the "leveraging rebates" theory - is close from the theories of harm used in tying cases, with the sole difference that it takes place on a single product. ${ }^{55}$

A short numerical example helps understand how leveraging rebates work in practice. Let us assume that firm A is dominant in the market for widgets. All customers source $70 \%$ of their products with firm A while firm B provides the remainder. A and B both sell for $10 €$ per unit, and incur an average cost of $5 €$ per unit. A wants to capture the $30 \%$ of demand currently served by B. It introduces the following rebate scheme: any customer that places more than $70 \%$ of its orders with $A$ will receive a price of $5 €$ per unit on all purchases. If customer $\mathrm{X}$ takes all of its requirements (100 units) with $\mathrm{A}$, he will pay $500 €$ to $\mathrm{A}$, that is $5 €$ per unit. To

\footnotetext{
${ }^{53}$ Where customers could in theory multi-source.

${ }^{54}$ In practice, a proxy for the calculation of the non-contestable share is the market share held by the dominant firm.

${ }^{55}$ So it escapes the single monopoly profit critique advanced by the Chicago school.
} 
keep serving X, B who is as efficient, could slash its prices to $5 €$ per unit. But this would not be sufficient to convince $X$ to stay with $B$. Indeed, in this variant, $X$ would pay $10 € \times 70$ to $A$ and $5 € \times 30$ to $\mathrm{B}$, that is $850 €$ in total. If firm B wants to compete for the $30 \%$ of $\mathrm{X}$, it must not only offer 30 at $5 €$, but also compensate loss of $5 €$ on 70 , ie $350 €$. To meet competition, B would have to effectively price as low as $30 \times 5 €-350 €=-200 €$. In other words, to stay in business, $\mathrm{B}$ would have to charge negative prices, that is to give $2 €$ per widget, to $\mathrm{X}$.

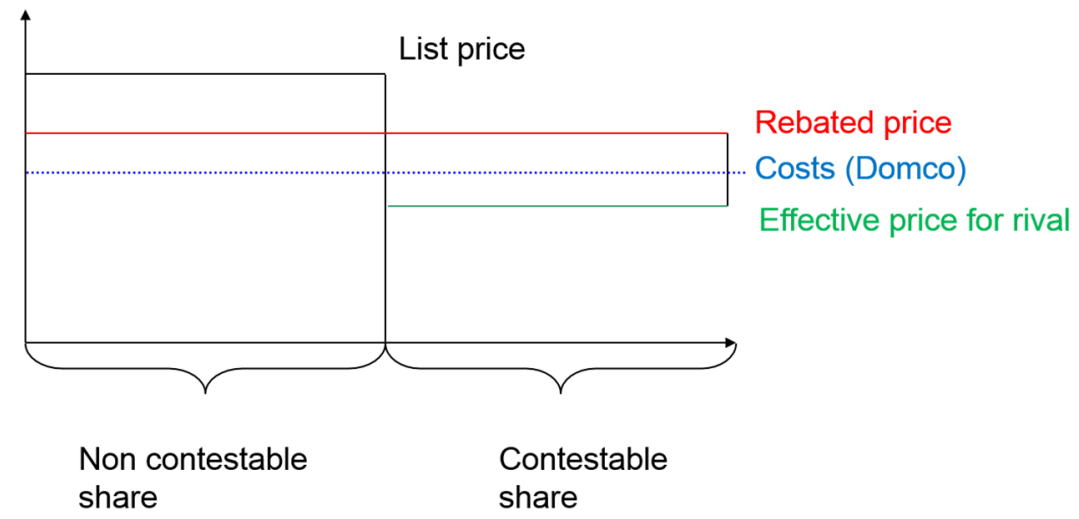

Figure 1 - Leveraging Rebates, Graphical Representation

The theory that leveraging rebates can yield anticompetitive exclusionary effects is based on several restrictive assumptions. ${ }^{56}$ One of them is that the rebate is applied to all customers in the market (or that $\mathrm{X}$ represents the entirety of market demand). However, if $\mathrm{X}$ is the only customer to enjoy the rebate in a market with 100 customers with equal requirements, then $\mathrm{B}$ can recoup the lost $200 €$ on 99 other customers. In this context, B will remain able to price compete with A at $6.98 €$ per unit, which is well below the initial $10 €$ per unit monopoly price. The rebate will thus certainly have an "exclusivity" effect with A. But short of a sufficiently large tied share, it will be incapable of exclusionary effects on B. At this stage, let us note that the Intel judgment does not pay much heed to this issue of the tied share, which it seems to assume as either large or, more plausibly, as irrelevant. ${ }^{57}$

Interestingly paragraphs 92-93 are not inventions of the Intel court. As said above, they draw heavy inspiration from traditional antitrust doctrine (and case-law). But readers will also recognize the language found in the 2009 Guidance Paper, an official agency document which ambitioned to bring some degree of legal certainty and economic literacy in single firm conduct cases. ${ }^{58}$ This document explains that the Commission focuses in priority on conduct

\footnotetext{
${ }^{56}$ Another one is that the rival firm cannot expand output, and challenge the dominant firm on the $70 \%$ of the requirements.

${ }^{57}$ Intel judgment, supra note 1, at paragraph 116.

${ }^{58}$ And bring the law of abuse of dominance in line with other areas of EU competition law (such as verticals agreements and mergers). In 2005, a group of influential academic economists appointed by the Commission (the Economic Advisory Group on Competition Policy, "EAGCP") suggested to modernize the approach inherited from the early Court case-law on abuse, and to undertake a real "verification of competitive harm" in abuse cases pursuant to an effects-based approach. More generally, the report proposed to use economics in a normative manner, with a view to defining legal tests for main categories of unlawful abuses. This suggestion paved the way to the adoption of a Commission Discussion Paper on 2009 which explicited substantive tests of abuse that were both consistent with existing case-law and inspired from modern industrial economics. The Discussion Paper was widely discussed in the competition community. In parallel, the Commission "tried" the effects-based approach in three abuse of dominance cases (i.e. the Wanadoo, Microsoft I and Telefónica cases). See http://ec.europa.eu/competition/antitrust/art82/index.html (accessed 11 May 2015). Commission Decision of
} 
that yields actual or potential anticompetitive foreclosure outcomes. ${ }^{59}$ At the same time, it formalizes an effects-based method for the assessment of unilateral practices under Article 102 TFEU. In a nutshell, this approach consists in laying down a theory of harm, testing it with price-costs assessments and counterfactual analysis, and considering efficiency defenses. ${ }^{60}$

The degree of semantical proximity between Intel and the Guidance Paper is arresting. Paragraphs 92-93 of Intel contain wording virtually identical to that used in the section of the Guidance Paper specifically devoted to rebates. Like the Guidance Paper which approached rebates as "exclusive purchasing obligations", Intel talks of "exclusivity rebates". ${ }^{61}$ Like the Guidance Paper which framed the issue in terms of anticompetitive "leverage", Intel explains that "the dominant firm can use its economic power ... as leverage". ${ }^{2}$ And like the Guidance Paper, Intel describes the mechanics of exclusivity rebates in terms of using the "noncontestable" portion of demand to capture the "contestable" share of demand.

Besides this, it is also important to see that the Intel Court speaks the language of mainstream antitrust economics. Intel discusses exclusivity rebates under the umbrella of the classic theory of anticompetitive leverage. The references found in the judgment to tying law make this particularly obvious. On several occasions, the Intel court talks of the "capability of tying customers to the undertaking in a dominant position". ${ }^{63}$

Against this backdrop, however, the imports of the Guidance Paper (and of mainstream economic theory) remain fractional. Whilst paragraph 92-93 of Intel explain how leveraging rebates can generate exclusivity, they remain mute on the scale of customer exclusivity necessary to yield competitor exclusion. On this, the Guidance paper stressed the necessity to review other factors, ${ }^{64}$ including the "position of the dominant undertaking", "conditions on the relevant market", "position of the dominant undertaking's competitors", "position of customers or input suppliers", "extent of the allegedly abusive conduct", "possible evidence of actual foreclosure", "direct evidence of any exclusionary strategy" ${ }^{65}$ Put differently, the Guidance Paper requires not only the proof of an exclusivity effect, but also of an exclusionary effect. ${ }^{66}$ In its decision, the Commission had established that the market share

16 july 2003, COMP/38.233 - Wanadoo Interactive; Commission Decision of 24 March 2004, COMP/C3/37.792 Microsoft; Commission Decision of 4 July 2007, COMP/38.784 - Wanadoo España v. Telefónica. Finally, the Commission adopted a Guidance Paper. The Guidance Paper marks a compromise between the Directorate General for Competition ("DG COMP") of the Commission, which initially pushed for the adoption of formal Guidelines on exclusionary abuses, and its Legal Service, intent on keeping a certain margin of maneuver before the Union courts.

${ }^{59}$ Abuse occurs if there is actual or likely elimination of an as efficient rival.

${ }^{60}$ In the words of former Director General LOWE: “The Commission now uses an 'effects-based approach' [...] which focuses on the actual and likely effects on consumer welfare. This means that a framework is needed to establish a theory of consumer harm, and this framework should also come up with hypotheses which can be tested (emphasis added)". See P. Lowe, "The Design of Competition Policy Institutions for the 21st Century The Experience of the European Commission and DG Competition", Competition Policy Newsletter, 2008 Number 3.

${ }^{61}$ Guidance paper, supra note 6, at paragraph 39.

${ }^{62}$ Idem.

${ }^{63}$ Intel judgment, supra note 1, at paragraph 86.

${ }^{64}$ Guidance paper, supra note 6, at paragraph 38.

${ }^{65}$ Guidance paper, supra note 6, at paragraph 20.

${ }^{66}$ If the core purpose of Article 102 TFEU is to prevent anticompetitive outcomes, this makes perfect economic sense. As explained previously, if the exclusivity rebate covers only $1 \%$ of market demand, as efficient rivals can keep competing to a certain extent with the dominant firm. 
tied by the fidelity rebates was significant, so that rivals were excluded from the market. ${ }^{67}$ The Intel court refused, however, to follow this path. Though it recognizes anticompetitive leverage as the engine of customer exclusivity, the judgment finds it unnecessary to condition findings of abuse to proof of exclusion. At paragraph 80, it affirms that "the question whether an exclusivity rebate can be categorized as abusive does not depend on an analysis of the circumstances of the case aimed at establishing potential foreclosure effects". ${ }^{6}$ At paragraph 85 , it holds again that "exclusivity rebates ... are by their very nature capable of restricting competition". 69 This means that once exclusivity rebates are detected, it is moot to "assess their effects on the market in their specific context". ${ }^{70}$ And this conflates exclusivity and exclusion for the purposes of applying Article 102 TFEU. Hammering out the consequences of this, the Intel court recapitulates: "the possible smallness of the parts of the market which are concerned by the practices at issue is not a relevant argument" ${ }^{71}$ and proof of significant foreclosure is not "a necessary condition". 72

The Intel judgment is also not entirely aligned with the Guidance Paper on the first step of the analysis, which is the characterization of exclusivity. To understand this, we would like to introduce a key distinction, that between exclusivity obligations and exclusivity options. On the one hand, there are exclusivity obligations: $\mathrm{X}$ commits under the contract to buy exclusively (or to buy 100\%) from A. On the other hand, there are exclusivity options - if X buys exclusively (or 100\%) from A, it will receive a financial or non-financial bonus. Exclusivity obligations can be unilateral - X commits under the contract to buy exclusively (or to buy 100\%) from A - or reciprocal - X commits under the contract to buy exclusively (or to buy 100\%) from A while A gives a something in exchange (possibly a financial or nonfinancial bonus). Exclusivity obligations can be presumed to generate exclusivity. Exclusivity options cannot. It all depends on what the buyer decides to do.

Fidelity rebates are exclusivity options. They cannot be abstractly presumed to generate exclusivity. If $A$ tells $X$ that it will get a rebate of $100 €$ if it purchases exclusively from it, it cannot be assumed that $\mathrm{X}$ will procure solely from $\mathrm{A} \cdot{ }^{73}$ It all depends on whether alternative suppliers can too give a $100 €$ rebate on the total price for the $30 \%$. Similarly, if A tells X that it will get a rebate of $0,5 €$ per unit above $80 \%$ of its requirements; of $1 €$ per unit above $90 \%$; and of $1,5 €$ per unit if it buys $100 \%$, it cannot be conjectured that $X$ will concentrate all or most of its purchases with A. ${ }^{74}$

The Guidance Paper had understood the distinction between obligations and options, and had formulated a simple quantitative method to evidence the exclusivity potential of fidelity rebates. It proposed to apply price-cost tests to calculate the effective price that ought to be

\footnotetext{
${ }^{67}$ Intel decision, supra note 11 at paragraphs 1577 and following.

${ }^{68}$ Intel judgment, supra note 1, at paragraphs 585 and 586. The Court affirms: "It should be noted that, in order to find that the exclusivity rebates were unlawful, the Commission is not required to analyse the capability of those practices to restrict competition according to the circumstances of the case at hand (see paragraphs 80 to 94 above)".

${ }^{69}$ And in other paragraphs, the Court states that this is because foreclosure (or exclusion) can be presumed, given that such rebates, though they do not render market access impossible, make "access to the market more difficult' to competitors. Intel judgment, supra note 1, at paragraph 88.

${ }^{70}$ Intel judgment, supra note 1, at paragraphs 89 and 143.

${ }^{71}$ Intel judgment, supra note 1, at paragraph 116.

${ }^{72}$ Intel judgment, supra note 1, at paragraph 120.

73 This is a de jure fidelity option if this is written in a contract.

74 This is a de facto fidelity option if this is written in a contract.
} 
matched by rivals. ${ }^{75}$ This method is the one that had been applied by the Commission in its decision.

In Intel, the Court crimps exclusivity obligations and options in the same box. It deems that any financial incentive is an unlawful "exclusivity rebate" when its grant is "conditional on the customer's obtaining all or most of its requirements" from the dominant firm. This definition is certainly justified on the ground that the dominant firm could otherwise evade the strict prohibition of exclusivity obligations by designing an exclusivity option. In other words, the prohibition rule shall not treat obligations and options distinctly, otherwise dominant firms could use options in an attempt to avoid the per se prohibition rule on exclusivity. ${ }^{76}$ This is presumably what the GC had in mind when it affirmed that fidelity rebates are not a pricing practice. ${ }^{77}$ Implicit in the GC reasoning is that exclusivity options are of the same breed as contractual exclusivity or, more generally, exclusive dealing.

But it is problematic. It is bound to capture as per se prohibited exclusivity rebates, options with no exclusivity potential. Let us revert to our numerical example, and think for a minute to the absurd example of $A$ giving a $1 €$ rebate on the total price of widgets if $X$ purchases $100 \%$ from it. This should be categorized as an exclusivity rebate under Intel's wisdom. However, the effective price that B will have to meet to compete with A will be $9,9 €$. With a cost per unit of $5 €, \mathrm{~B}$ remains perfectly apt to serve $\mathrm{X}$, and exclusivity cannot be presumed. The impropriety of the confusion between obligation and options is further compounded by the fact that the Intel court does not specify what "all or most" means. With all this, it appears difficult to maintain that the Intel court abrogates the Guidance Paper. Rather, it is quite clear that Intel ratifies the Guidance Paper reasoning. ${ }^{78}$ At the same time, however, it does not draw all the operational consequences from it. This is a little confusing.

\section{NON-LEVERAGING REBATES AND THE RULE OF REASON}

The judicial recognition of the theory of leveraging as the lynchpin for the prohibition of certain dominant firms' rebates brings a crucial limitation to the scope of the per se prohibition rule on exclusivity rebates: non-leveraging rebates escape the per se prohibition rule applicable to rebates of the second category.

Let us unwrap again the Intel's court operative reasoning. Exclusivity rebates are subject to a strict per se prohibition rule. ${ }^{79}$ This is because the dominant firm can maneuver the "non contestable share" of demand as leverage to capture the "contestable share". Rivals willing to compete do not stand a chance to behave equally - they do not enjoy a non-contestable share. They must therefore offer "compensation for the loss of exclusivity rebate" on the contestable share. This arguably makes their life "more difficult", and is a cause of antitrust concern. Leveraging rebates, those granted on the contestable share, plus on all or part ("all or most" says the Court) of the non-contestable share shall hence be deemed per se unlawful.

\footnotetext{
75 The Guidance paper proposed to impute the amount rebated on the non-contestable share to the contestable share.

${ }^{76} \mathrm{I}$ am grateful to R. Whish for pointing this argument to my attention.

${ }^{77}$ Intel judgment, supra note 1, at paragraph 99.

${ }^{78}$ Guidance paper, supra note 6, at paragraphs 37-45.

${ }^{79}$ Intel judgment, supra note 1, at paragraph 93 and 178.
} 
And the implicit corollary of this is an admission that rebates that do not operate through a leveraging effect are of less concern, and shall be removed from the per se prohibition rule. In all logic, the standard that ought to apply to them should be the next less strict standard, ie the rule of reason analysis applicable to rebates of the third category. For those rebates, it is "necessary to consider all the circumstances". ${ }^{80}$

In practice, this is no little finding. Dominant firms are not per se barred from granting rebates on the contestable share of demand. What is per se forbidden is to grant rebates on the contestable units, plus on some or all of the non-contestable quantities. As a rule of thumb, the non-contestable share can be approximated to the dominant firm's market share. If we re-use our example, firm A is not per se barred from granting a rebate to $\mathrm{X}$ on the $30 \%$ open to competition (for instance, $\mathrm{X}$ receives a $10 \%$ rebate on all quantities exceeding $75 \%$ of its requirements). However, $\mathrm{A}$ is per se banned from offering a rebate that covers the $30 \%$ open to competition plus a share of the $70 \%$ not open to competition. ${ }^{81}$

The difference between leveraging and non-leveraging rebates mimics the Guidance Paper's distinction between retroactive rebates and incremental rebates. ${ }^{82}$ Whichever may be the right qualification, the per se prohibition rule against exclusivity rebates defined in Intel targets leveraging rebates. And with this definition, the Intel Court has rejected non-leveraging rebates in the rule of reason box (third category). This mitigates early concerns that dominant firms active in the EU are no longer free to price compete. As long as they stay within the limits of the contestable share, they can price compete. ${ }^{83}$

\begin{tabular}{|c|c|c|}
\hline Type of rebate & Test in Guidance Paper & Test in Intel \\
\hline Quantity rebate systems $(\S 75)$ & Per se legality & Per se legality (Michelin II) \\
\hline Leveraging rebates $(\S 76)$ & $\begin{array}{c}\text { Rule of reason (quantitative } \\
\text { price test + objective } \\
\text { justification) }\end{array}$ & $\begin{array}{c}\text { Per se illegality (Hoffmann-La } \\
\text { Roche) }\end{array}$ \\
\hline Non-leveraging rebates & $\begin{array}{c}\text { Rule of reason (quantitative } \\
\text { price test + objective } \\
\text { justification) }\end{array}$ & Rule of reason \\
\hline
\end{tabular}

\footnotetext{
${ }^{80}$ Intel judgment, supra note 1, at paragraph 78 which deems necessary "to consider all the circumstances, [...] and to investigate whether, [...], that rebate tends to remove or restrict the buyer's freedom to choose his sources of supply, to bar competitors from access to the market, or to strengthen the dominant position by distorting competition".

${ }^{81}$ On paper, this principle seems easy to apply, but it may be very complex for dominant firms to implement it in practice.

${ }^{82}$ Guidance paper, supra note 6 , at paragraph 40 . A rebate is "retroactive" when the price concession is granted on all purchases during a defined period, including those below the specified threshold(s). It is "incremental" when the price concession benefits to purchases above the threshold(s). The Guidance paper suggests to administer complex price-costs tests to establish anticompetitive foreclosure. It stresses that anticompetitive foreclosure is more likely and acute where the conditional rebate is retroactive. The Guidance Paper distinction is not bullet proof, because some incremental rebates can generate leveraging, if the threshold for the grant of the rebate is specified at a level inferior to the dominant firm market share.

${ }^{83}$ This makes perfect sense, because a rebate in the contestable share of a dominated market will not cover "all or most" of customers' purchases, in the sense of the definition of the Intel judgment, supra note 1, at paragraph 76.
} 
Rebates not linked to a condition of exclusive or quasi exclusive supply $(\$ 78)=>$ individual sales targets
Rule of reason (quantitative price test + objective justification)
Rule of reason ("consider all the circumstances" Michelin I)

\section{Justifiability Defence And the Modified PeR SE Prohibition of LeVeraging REBATES}

The perception that Intel embodies a per se prohibition rule against fidelity rebates is additionally discredited by paragraph 94 of the judgment, which articulates a justifiability defence for exclusivity rebates. It is said there that dominant firms can:

"justify the use of an exclusivity rebate system, in particular by showing that its conduct is objectively necessary or that the potential foreclosure effect that it brings about may be counterbalanced, outweighed even, by advantages in terms of efficiency that also benefit consumers"

In other words, efficient exclusion exists.

Again, this idea does not significantly move existing law. Under the Guidance Paper, ${ }^{84}$ and the Post Danmark case-law of the CJEU,${ }^{85}$ dominant firms could already attempt to justify exclusionary conduct, and redeem it from Article 102 TFEU liability. ${ }^{86}$ Even before, Hoffmann-La Roche ${ }^{87}$ envisioned an integrated Article 102 TFEU defence with a (somewhat ambiguous) reference to Article 101(3) TFEU. ${ }^{88}$

What is remarkable, however, is that Intel affirms this derogation for the first time in the context of appeals proceedings. Moreover, the Court's statement reads like obiter dicta. Intel had indeed not put forward any such defence in its appeal. ${ }^{89}$

The legal test thus applicable to exclusivity rebates comes nowhere close to a per se prohibition rule. Surely, as soon as leveraging rebates are identified, liability is presumed. But this is not the end of the story. The burden of proof is then deflected on the dominant firm, which can put forward economic efficiencies ${ }^{90}$ or objective necessities ${ }^{91}$ to justify its

\footnotetext{
${ }^{84}$ See Guidance paper, supra note 6, at paragraphs 28-31 and $\$ 46$ in relation to rebates.

${ }^{85}$ Post Danmark judgment, supra note 51, at paragraphs 40-2.

${ }^{86}$ Intel judgment, supra note 1 , at para. 81.

${ }^{87}$ Hoffmann-La Roche judgment, supra note 7, at para. 90

${ }^{88}$ Article 101(3) exempts pro-competitive coordination from liability.

${ }^{89}$ This can be explained by the fact that Intel denied the very existence of exclusivity in the first place, so pleading a justification for exclusivity would have been a strange, paradoxical legal strategy. Moreover, it is reasonable to think that if the Commission chose to apply a strict per se or quasi per se prohibition standard during the investigation, in line with the Hoffmann-La Roche precedent, this left no room to Intel to plead efficiencies.

${ }^{90}$ Here is an example of an efficiency benefit. Let us imagine that the rebate granted to X brings about an additional increase in efficiency for $\mathrm{A}$, so that its average production cost falls to $4 €$ /unit. The rebate brings about efficiency that did not exist before. Assuming that B was an as efficient rival pre-rebate (at $5 € /$ unit), this would not prevent to find the rebate efficiency enhancing
} 
conduct. With all this, the Intel liability standard can be better classified as a modified per se prohibition rule.

The concrete application of the justifiability defense could, however, be problematical. The reason for this is self-evident. Under Intel, the anticompetitive effects of leveraging rebates are presumed. Agencies and or complainants before courts do not need to substantiate claims of abuse with estimates of harm to competition. But how can the dominant firm then effectively invoke efficiencies that "counterbalanc[e]" or even "outweig[h]" the anticompetitive harm caused by its leveraging rebates if it does not know the magnitude of those effects in the first place? Intel's modified per se standard implies that dominant firms argue efficiencies in the dark. This asymmetry between the liability and justifiability prongs of Article 102 TFEU is even more compounded when, following Intel, most of the quantitative benchmarks of possible use to establish liability are declared irrelevant by the Court (tied market share, tied customer share, size of rebates). ${ }^{92}$

\begin{tabular}{|c|c|c|}
\hline Type of rebate & Test in Guidance Paper & Test in Intel \\
\hline Quantity rebate systems (\$75) & Per se legality & Per se legality (Michelin II) \\
\hline Leveraging rebates (\$76) & $\begin{array}{c}\text { Rule of reason (quantitative price } \\
\text { test + objective justification) }\end{array}$ & $\begin{array}{c}\text { Modified per se illegality (no } \\
\text { harm verification + objective } \\
\text { justification) }\end{array}$ \\
\hline $\begin{array}{c}\text { Non-leveraging rebates } \\
\text { Rule of reason (quantitative price } \\
\text { test + objective justification) }\end{array}$ & Rule of reason \\
\hline $\begin{array}{c}\text { Rebates not linked to a condition } \\
\text { of exclusive or quasi exclusive } \\
\text { supply (\$78) }=>\text { individual sales } \\
\text { targets }\end{array}$ & $\begin{array}{c}\text { Rule of reason (quantitative price } \\
\text { tests + objective justification) }\end{array}$ & Rule of reason \\
\hline
\end{tabular}

\section{Positive LAW IMPLICATIONS}

It is now time to close the positive law discussion. At this stage, the outstanding question is whether the liability regime for leveraging rebates defined in Intel - as well as the pronouncements of the Intel court on other types of rebates and on abuse in general constitutes the positive law of Article 102 TFEU that must be applied by the Commission, the national agencies and courts in ongoing and future competition cases. The implicit, related question is whether Intel supplants the approach enshrined in the Commission's Guidance Paper. This issue can be approached from two vantage points: the formal (1) and the

\footnotetext{
${ }^{91}$ Here is an example of an objective necessity. Let us imagine, for a minute, that $\mathrm{X}$ is a new customer of A. By virtue of the contract, A will undertake certain relation specific investments. A will for instance finance basic point of sale infrastructure as well as training costs. The rebate may be an appropriate means to ensure X fidelity to $\mathrm{A}$, and that $\mathrm{B}$ does not free ride on $\mathrm{A}$ investments. This would fall within the category of an objective necessity.

${ }^{92}$ Intel judgment, supra note 1, at paragraph 150. For instance, dominant firms' own costs do not longer constitute a relevant benchmark.
} 
substantive applicability (2) of the Guidance Paper.

\section{Formal Applicability}

In terms of formal applicability, the Commission's Guidance Paper remains unscathed by Intel. As is well known, appeals before the General Court are review proceedings. They are time-specific, unlike other judicial remedies like preliminary references before the CJEU. One should thus not try to read too much about the Guidance Paper in Intel, which concerns a case started in the early 2000, well before the Commission decided to change its Article 102 TFEU policy in 2009. And nothing should prevent the Commission from applying its Guidance Paper in post-2009 cases. ${ }^{93}$ The Intel court said just this when it confirmed that the "Article 82 Guidance was not applicable in the present case", thereby implicitly not ruling out its applicability for subsequent cases. ${ }^{94}$

General principles of EU administrative law could even lend credence to the idea that the Commission has a duty to apply its Guidance Paper to post-2009 cases. The Court has often recognized that soft law instruments bind the Commission through a form of "Estoppel". This idea has several possible roots in EU legal theory. In Dansk Rørindustri and others, the Court tied it to the general principle of legitimate expectations. In relation to "rules of conduct designed to produce external effects, as is the case of the Guidelines, which are aimed at traders", it held that:

"In adopting such rules of conduct and announcing by publishing them that they will henceforth apply to the cases to which they relate, the institution in question imposes a limit on the exercise of its discretion and cannot depart from those rules under pain of being found, where appropriate, to be in breach of the general principles of law, such as equal treatment or the protection of legitimate expectations. It cannot therefore be precluded that, on certain conditions and depending on their content, such rules of conduct, which are of general application, may produce legal effects". ${ }^{95}$

In Archer Daniels Midlands, the Court followed a different route to affirm the same principle. It noted that:

"Guidelines are capable of producing legal effects. Those effects stem not from an attribute of the Guidelines as rules of law in themselves, but from their adoption and publication by the Commission". 96

Whichever the right legal theory may be, the EU Courts seem to attach binding effects to such instruments. ${ }^{97}$ The Fining Guidelines, the Leniency Notice or the De Minimis Communication are all examples of soft law instruments which bind the Commission in its enforcement initiatives. And there is no reason why the Guidance Paper should escape a

\footnotetext{
${ }^{93}$ And possibly to prior cases, for the Court recognized that the Commission could, "for the sake of completeness" apply more demanding economic standards. See Intel judgment, supra note 1, at paragraph 586.

94 Idem, paragraph 158.

${ }^{95}$ Joined Cases C-189/02 P, C-202/02 P, C-205/02 P to C-208/02 P and C-213/02 P Dansk Rørindustri and Others $v$ Commission [2005] ECR I-5425, paragraph 211

${ }^{96}$ Case T-59/02 Archer Daniels Midland v Commission [2006] ECR II-3627, paragraph 43

${ }^{97}$ O. STEFAN, Soft Law in Court - Competition Law, State Aid and the Court of Justice of The European Union, Kluwer, 2013; N. PETIT and M. RATO, "From Hard to Soft Enforcement of EC Competition Law - A Bestiary of Sunshine Enforcement Instruments", in C. GHEUR and N. PETIT (Eds.), Alternative Enforcement Techniques in EC Competition Law, Bruylant (2008).
} 
similar fate. On its face, the Guidance Paper is a "Communication from the Commission", published in the Official Journal of the EU. It was adopted following a lenghty consultation process on Article 102 TFEU. And in terms of substance, it goes into a high degree of granularity at defining standards of Article 102 TFEU liability.

That the Guidance Paper explicitly disclaims at paragraph 3 that it "is not intended to constitute a statement of the law" or that its title speaks of "enforcement priorities" changes nothing to the analysis. EU practitioners and scholars may be interested to fret on the surreal impression left by a Communication that says that it is not a statement of the law, but that at the same time spends 27 pages defining structured tests of liability. But this is irrelevant. Like other instruments that convey "rules of practice", the Guidance Paper binds the Commission.

There is, however, a significant limitation to the Guidance Paper formal applicability. Its binding effect does not cover the national competition agencies and courts. In Pfleiderer and Expedia, the Court clarified that Notices adopted by the Commission exert no binding effect on Member States authorities (though they can influence their decisional practice). ${ }^{98}$ The national agencies and courts are thus free to apply whatever Article 102 TFEU doctrine they want, though it is clear that they will face difficulty to apply Article 102 TFEU distinctly from the Guidance Paper given their duty of convergence under Article 11 of Regulation 1/2003. ${ }^{99}$

\section{Substantive Applicability}

The formal applicability of the Guidance Paper in positive competition law does not mean that the tests of liability it embodies enjoy substantive validity. In Solvay and British Airways, Advocate General KOKOTT made the following important point:

"even if its administrative practice were to change, the Commission would still have to act within the framework prescribed for it by Article [102 TFEU] as interpreted by the Court of Justice". ${ }^{100}$

In Post Danmark, the Grand Chamber of the CJEU has already seized the opportunity to confirm the general approach of the Guidance Paper. But the CJEU is yet to rule on the compatibility of the novel standards of liability introduced by the Guidance Paper in relation to the various categories of abuse.

Whilst the CJEU is the sole jurisdiction with decisive authority on those issues, ${ }^{101}$ the Intel court has seemed willing to deliver some subliminal hints on the substantive validity of the Guidance Paper. This can be seen in the commencement of the judgment, which starts with a section discussing the "legal characterization" of abusive rebates which contains no facts but

\footnotetext{
${ }^{98}$ Case C-360/09 Pfleiderer [2011] ECR I-5161; Case C-226/11, Expedia, ECLI:EU:C:2012:795

${ }^{99}$ Council Regulation (EC) No 1/2003 of 16 December 2002 on the implementation of the rules on competition laid down in Articles 81 and 82 of the Treaty [2003] OJ L1/1.

100 C-109/10P, Solvay SA v Commission, [2011] ECR I-000, paragraph 21; C 95/04 British Airways v Commission, [2007] ECR I-2331, paragraph 28.

${ }^{101}$ It may be tested in the context of appeals on points of law introduced against judgments of the GC reviewing Commission decisions adopted pursuant to the Guidance Paper or in the context of preliminary rulings under Article 267 TFEU.
} 
law. ${ }^{102}$ This kind of academic presentation is uncommon, if not unprecedented, in review judgments of the General Court. There is therefore a credible point that the Intel court sought to convey principled messages on the Guidance Paper substantive applicability in its judgment. ${ }^{103}$

That the Intel court spoke on the Guidance Paper can thus be safely assumed. But should we listen? Despite all that has been said above, a word of caution is needed here. The intellectual integrity of the Intel court's pronouncements on the standard of liability applicable to dominant firms' rebates is questionable. The section of Intel on the "legal characterization" of abusive rebates exhibits a parade of dubious, inconsistent and selfcontradicting references to the CJEU case law on exclusionary abuses. In essence, the General Court seems to follows a referencing pattern which consists in dismissing precedents when they are adverse to the defendant, and upholding the same precedents when they are supportive of the defendant's position.

Take TeliaSonera, a leading CJEU judgment on margin squeeze. ${ }^{104}$ In its appeal, Intel was seeking support in paragraph 28 of TeliaSonera, which states that "to prove an abuse it is necessary to prove all the circumstances". The GC dismissed the applicability of TeliaSonera in the case. It ruled that TeliaSonera was "limited to pricing practices". It was thus inapplicable to the case under review, which concerned exclusivity rebates (which the Court disputably refuses to categorize as a pricing practice). ${ }^{105}$ Having read that TeliaSonera is irrelevant in the case, one does not expect to see it reappear subsequently in the reasoning. This notwithstanding, the Intel court cites to TeliaSonera at paragraph 103 to relieve the Commission from the duty to establish that the rebates had "actual effects" on competition... ${ }^{106}$

The landmark Post Danmark judgment of the Grand Chamber of the CJEU is given a similar treat. Like for TeliaSonera, the Intel court refutes its precedential value on the ground that Post Danmark concerned above-cost "pricing practices". Intel could thus not seek legal shelter in Post Danmark's rule of reason-inspired wording. ${ }^{107}$ However, at paragraph 94 of its judgment, the Court cites to Post Danmark as precedent to explain that exclusivity rebates can be salvaged from prohibition if they yield redeeming efficiency advantages or if they are objectively necessary... ${ }^{108}$

\footnotetext{
${ }^{102}$ Intel judgment, supra note 1, at paragraphs 72 to 94 . It is commonplace in the antitrust world that this unusual structure of the judgment came from the fact that the Intel had built its appeal this way. This led the GC to make numerous references to the Article 102 case-law of the CJEU, which contain indications on the "framework" for the application of Article 102 TFEU mentioned in AG KOKOTT's opinion under British Airways.

103 The General Court is the second best-placed court in the EU to render an authoritative interpretation of Article 102 TFEU. Moreover, the substance of the decision deferred to its review was Guidance Paper-spirited, given that the Commission had carried out the Intel investigation as a test case. In parallel with the Intel investigation, the Commission was drafting its Guidance Paper. Prior to casting a standard of abuse in stone, the Commission may have used the Intel investigation as a test case for the practicability of the Guidance Paper approach. This is good administrative policy, and there is no need to dwell too long on this. The consequence of this is that the judgment indirectly gives indications on the substantive validity of the Guidance Paper.

${ }^{104}$ Case C-52/09 Konkurrensverket v TeliaSonera Sverige AB [2011] ECR I-527.

${ }^{105}$ Idem at paragraph 56 et seq. (despite the fact that Hoffmann-La Roche talked of the grant of a financial advantage, see Hoffmann-La Roche judgment, supra note 7, at paragraph 90).

106 When it reviews the circumstances of the case.

${ }^{107}$ Intel judgment, supra note 1, at paragraph 99.

${ }^{108}$ Intel judgment, supra note 1, at paragraph 94.
} 
This pattern of fallacious interpretations perpetuates with the exclusion of the Tomra judgment. The Intel court spells rightly that Tomra concerned "individualised retroactive rebates", in line with the applicant's argument. ${ }^{109}$ But it then qualifies the rebates discussed in Tomra as rebates belonging to the "third category", ie those "where the grant of a financial incentive is not directly linked to a condition of exclusive or quasi-exclusive supply". Given that Intel's rebates were falling under the second category, the GC thus finds that the Tomra standard is inapplicable in Intel. ${ }^{110}$ But in so doing, it turns a blind eye on the fact that it previously cited its own judgment in Tomra to justify the categorization of Intel's practices as second category "exclusivity rebates"...111

But the flaw in citation is nowhere more clearly displayed than in relation to the Van den Bergh Foods judgment. ${ }^{112}$ This case was about a dominant ice cream supplier that had tied retail outlets in Ireland with de facto exclusivity commitments. The dominant firm had offered free freezer cabinets to space constrained retailers, and imposed on them a contractual duty to exclusively store its own ice cream within the cabinets. The Commission and the GC established an abuse, on the ground that $40 \%$ of the retail outlets were foreclosed by the tie.

In its appeal, Intel was seeking support in Van den Bergh Foods to claim that the Commission should have proved that the tied share was "significant" (in Intel's computation, it represented 14\%). The Intel Court stroke the argument down on the ground that the Van den Bergh foods judgment "did not concern a practice by which a financial incentive was directly conditional on the customer's obtaining all or most of its requirements from the undertaking in a dominant position". ${ }^{113}$ The misreading of the Van den Bergh Foods case-law is mesmerizing. The GC itself, in the Van den Bergh Foods judgment held at paragraph 159 that the "infringement of Article 86 [now Article 102 TFEU] takes the form, in this case, of an offer to supply freezer cabinets to the retailers and to maintain the cabinets free of any direct charge to the retailers". If offering a product for free is not a "financial incentive", then little green men exist. ${ }^{114}$

In our view, the truly spectacular number of inconsistencies affecting the Intel judgment's referencing contaminates the credibility of the General Court's pronouncements. Unfortunate as this may be - especially in terms of legal certainty - the section devoted to the "legal characterization" of abusive rebate should thus be disregarded, because it lacks substantive authority. ${ }^{115}$

\section{E. SUMMATION}

\footnotetext{
${ }^{109}$ Intel judgment, supra note 1, at paragraph 97.

${ }^{110}$ Intel judgment, supra note 1, at paragraph 97.

${ }^{111}$ Intel judgment, supra note 1, at paragraph 77.

112 Case T-65/98, Van den Bergh Foods Ltd v Commission [2003] ECR II-4653.

${ }^{113}$ In so saying, the Court implicitly recognizes that Intel's rebates constituted a pricing practice.

${ }^{114}$ As if this was not enough, the Intel court confuses sources. It asserts, for instance, that "The Court of Justice has [...] rejected the application of an 'appreciable effect' criterion or a de minimis threshold for the purposes of applying Article 82 EC", but cites as support an Opinion of an Advocate General... Intel judgment, supra note 1, at paragraph 116, citing Opinion of Advocate General Mazák in Case C-549/10 P Tomra, supra note 35.

115 The falsification of references by the EU Courts is not unprecedented in the case-law. Professor COUTRON has devoted an extensive study to this issue. He concludes that the European courts occasionally manipulate precedents, and provides evidence of this phenomenon. See L. COUTRON, "Style des arrêts de la Cour de justice et normativité de la jurisprudence communautaire", (2009) 45(4) Revue Trimestrielle de Droit européen, pp. 643-676.
} 
To recapitulate, two options exist. Some may consider that the Intel judgment can be formally and substantively disregarded for the assessment of abusive conduct post 2009. In this context, the Guidance Paper remains formally and substantively applicable, and the debate on its substantive applicability will have to be settled by the Court in the context of other proceedings. ${ }^{116}$ Others may find Intel authoritative, and pluck in it some hints on the positive law of dominant firms' exclusivity rebates. In this variant, a modified per se prohibition rule applies to exclusivity rebates. And this standard only covers a subset of practices, ie leveraging rebates. Other rebates shall be subject to the rule of reason, in line with the "more economic", effects-based spirit of the Guidance Paper.

\section{INTEL AND THE GOALS OF ARTICLE 102 TFEU}

\section{A. CONCEPTUAL FRAMEWORK}

The Intel court consistently repudiates the need to establish actual or likely anticompetitive effects in exclusivity rebates cases. That position tells as much in relation to evidence than it says on the goals of abuse of dominance. With this, the Intel court whispers that the prohibition rule of Article 102 TFEU does not aim at remedying anticompetitive outcomes, in the form of market exclusion. This strays from the "effects-based" philosophy advocated in the Guidance Paper. And even more fundamentally, this seems to dismiss the relevance of the "outcome" paradigm in EU abuse of dominance law. The outcome paradigm - also known as the "welfarist", "output" or "efficiency" paradigm - can be traced to the Chicago school, and in particular to the works of Robert BORK and Richard POSNER. It is controversial. Professor Eleanor FOX wrote once that "it is a crabbed perspective that [is] intended to and does minimize antitrust law". 117

Instead, the Court inks out that the basic concern undergirding Article 102 TFEU is to ensure that rivals' "access to the market" (or supply to customers) is not made "more difficult", and this regardless of whether rivals are or not foreclosed. ${ }^{118}$ This is repeated at least two dozen times in the judgment. ${ }^{119}$

In practice, the idea that it is abusive for a dominant firm to make rivals' access "more difficult" is challenging. For instance, monopoly pricing is what makes rivals' life the least difficult. Should the monopoly price thus be the lawful pricing point for the dominant firm enjoined to end abusive rebates?

It is not those practicalities that we want to discuss here. Rather, building on the early scholarship that reads in Intel a plain rejection of any outcome-related goal in Article 102 TFEU law, our intention is to elicit what alternative, non-outcome goal(s) lurks behind the slogan that rivals' access be not made more difficult. ${ }^{120}$ Like in the US where a rich theological debate has arisen due to Congress's reluctance to articulate the goals of the Sherman Act, the EU Treaties have never clearly explicated the goals of the competition

\footnotetext{
${ }^{116}$ Rumour has it that within the Commission, some officials informally consider that keeping the Guidance Paper alive would be akin to contempt of court.

${ }^{117}$ E. M. FOX, "The Efficiency Paradox" (July 8, 2009), How the Chicago School overshot the Mark: The Effect of Conservative Economic Analysis on U.S. Antitrust, R. PITOFSKY, ed., Oxford, p. 77, 2008; at p.79.

${ }^{118}$.See, for instance, Intel judgment, supra note 1, at paragraph 93.

119 There may well be a market outcome problem, but it comes from dominance.

${ }^{120}$ The debate on rebates is also often phrased in terms of pros and cons of per se-or quasi per se - rules. Some have advanced that per se rules are appropriate because they provide significant legal certainty as well as reduced enforcement costs. But this cannot be a good argument for the discussion, for a rule of per se legality would be conducive to the same result.
} 
rules. And the Intel court's pronouncements to the effect that competitive outcome is not the lynchpin of Article 102 TFEU, is not accompanied by the explicit formulation of an alternate non-outcome paradigm.

We may approach the topic by reviewing what the antitrust literature has to say about nonoutcome goals. In this perspective, the idea that Article 102 TFEU seeks to prevent rivals' from being made "more difficult" can be tied to three distinct theoretical goals, which have been fiercely discussed in US antitrust scholarship. We describe and debate all three goals, their merits and flaws, with a view to assess their possible acclimation in the EU competition law order. As will be seen, none of them seems importable in the EU legal and economic system. And none of them wears away the necessity to apply economics in the decision making process.

\section{B. COMPETITIVE PROCESS}

The first goal possibly attributable to Article 102 TFEU is the protection of the "competitive process". Though it is nowhere mentioned in the Intel judgment, there is good reason to discuss it first. Professor FOX rightly describes the competitive process as the polar opposite of the outcome paradigm that dominates contemporary US antitrust policy and the Guidance Paper. ${ }^{121}$ So if the postulate is right that Intel strays from the Guidance Paper's spirit, it is logical to start with a review of its antithesis. In addition, the bare language of Intel alludes to concepts like the "structure of competition", "market access" or competition on the "merits" which are often viewed as corollaries of the competitive process. Eleanor FOX herself uses interchangeably notions such as "process-and-access approach", "competitive structure", "openness of the market", "rivalry", etc. Lastly, senior members of the EU Commission legal service - the finest experts of EU statutory interpretation - have often contented in public that the Court's case-law on Article 102 TFEU seeks to protect the competitive process. ${ }^{122}$

Let us thus explore the ramifications of the "competitive process" goal. Professor FOX has advanced the following description of the paradigm:

"Maintaining an environment congenial to mavericks and upstarts; an environment that induces firms to be rivalrous, to seek new ways to reduce their own costs, and to vie to meet buyers' wants. A task of antitrust is to prevent this dynamic process from being undermined. Therefore, preserving access by outsiders, preserving contestability of markets, and at high levels of concentration, valuing diversity, are seen as mechanisms of efficiency. Preventing inefficient outcomes is also an objective, but safeguarding the process is the first-line protector against bad outcomes". ${ }^{123}$

In FOX's view, the competitive process should be protected as a first-order objective, because it reins in the risk of anticompetitive outcomes.

Wouter WILS, a former member of the Legal Service, and also a backer of the competitive process paradigm, has developed a distinct interpretation. ${ }^{124}$ In his view, the competitive process should not be protected because of the belief that it delivers positive results in terms

\footnotetext{
${ }^{121}$ FOX, supra note 118 , at p. 86.

${ }^{122}$ Idem. FOX, in line with this considers that the EU "values openness', access, rivalry and the competitive structure of markets as mechanism to produce economic welfare, competitiveness, innovation and market integration".

123 Idem, at p.80

${ }^{124}$ W. P. J. WILS, "The Judgment of the EU General Court in Intel and the So-Called 'More Economic Approach' to Abuse of Dominance" (September 19, 2014). World Competition: Law and Economics Review, Vol. 37, No. 4, 2014.
} 
of consumer welfare. Rather, the competitive process must be protected for its own sake. WILS' argument rests on Austrian economics theory, and in particular on the works of Friedrich HAYEK who viewed competition "as a procedure for the discovery of such facts as, without resort to it, would not be known by anyone, or at least would not be utilise". ${ }^{125}$ Accordingly, WILS finds no place for "welfarist", outcome, or output considerations in Article 102 TFEU enforcement.

In an undeservedly discrete paper, ${ }^{126}$ Professors Aaron EDLIN and Joe FARRELL have attempted to reconcile the welfarist and non-welfarist readers of the competitive process. ${ }^{127}$ EDLIN and FARRELL are also supporters of the competitive process paradigm. ${ }^{128}$ Their ambition is to articulate a formalised definition of the competitive process, noting that "Courts ... frequently stress the competitive process, even when they may not be particularly clear about what that process is". ${ }^{129}$

At a stylised level, EDLIN and FARRELL define the competitive process as "the process of sellers and buyers forming improving coalitions". In mundane words, it is the "freedom to strike better deals". If firm A is inefficient, customers should remain free to trade with B at their mutual betterment. This dynamic process implies a form of creative destruction, reminiscent of the Schumpeterian tradition.

In addition, EDLIN and FARRELL introduce an outcome, welfarist or efficiency dimension in their definition. In their view, an economy subject to the competitive process evolves towards an optimum labelled the "core", which corresponds to the set of all allocations that leaves no coalition of traders in a position to improve the payoffs of all its members. ${ }^{130}$ Alternately put, the core is a Pareto efficient outcome.

In their paper, EDLIN and FARRELL proceed to build a theory of harm to the competitive process in a single firm conduct context. The baseline is that a "monopoly may not block improving trade between customers and rivals who would offer customers a better deal". In a monopoly setting, this can however happen because rivals may have to compete against a virtual price lower than the actual price paid by the customers of the dominant firm. To explain this, EDLIN and FARRELL propose the simple following model. The monopolist $\mathrm{M}$ charges a high price $\mathrm{H}$, but would cut it to a low price $\mathrm{L}$ in case of entry. Rival(s) R knows L, and cannot compete at this level. But $\mathrm{R}$ could offer a median price PM lower than $\mathrm{H}$ that would improve the situation of customers. In spite of this, however, $\mathrm{R}$ will not enter, conjecturing retaliation at $\mathrm{L}$. Customers will be deprived of an improvement. In the model, $\mathrm{R}$ compete with a virtual price lower than that actually charged to customers. ${ }^{131}$

EDLIN and FARRELL concede a conceptual flaw in their model, notably that L represents an ex post improving coalition if entry occurs. ${ }^{132}$ But in our view, an even more fatal defect vitiates their model. In real markets, there are only two possible states of the world. In the

\footnotetext{
${ }^{125}$ F.A. HAYEK, 'Competition as a Discovery Procedure', in New Studies in Philosophy, Politics, Economics and the History of Ideas (University of Chicago Press, 1978), 179 at 179.

126 This paper was pointed out to us by a member of the EU Commission legal service a year ago.

${ }^{127}$ A. EDLIN and J. FARRELL, "Freedom to Trade and the Competitive Process", NBER Working Paper No. 16818, issued in February 2011.

128 They side with the "courts in thinking that an analysis of impacts on the competitive process should remain central to antitrust". Idem, p.2.

${ }^{129}$ The paper considers that both process and outcomes matter, but focuses on the former.

${ }^{130}$ R. J. AUMANN, "Existence of Competitive Equilibria in Markets with a Continuum of Traders", Econometrica Vol. 34, No. 1 (Jan., 1966), pp. 1-17.

${ }^{131}$ In plain language, this could be labelled ghost limit pricing.

${ }^{132}$ M's post entry price of L represents ex post an improving coalition of M and customers', relative to R's offer.
} 
first state of the world - that imagined by EDLIN and FARRELL - R know L. There is perfect (or quasi-perfect) information. The reasons for this situation of informational perfection may be diverse: $\mathrm{M}$ may have disclosed $\mathrm{L}$ in the past during a previous anti-entry campaign; $M$ may be subject to a regulatory duty (to disclose cost information, to approximate prices to cost, etc.); the product manufactured by $\mathrm{M}$ is a commodity, technology is mature, etc.; $\mathrm{M}$ has explicitly threatened $\mathrm{R}$ from $\mathrm{L}$ through press announcements, etc. The bottom line is that in all these cases, there is market transparency on L. With this in mind, it should be equally, and safely, assumed that customers are also aware of L (especially if they are experienced industrial customers). This, in turn, has a critical implication: customers can and will first seek to form an improving coalition with $\mathrm{M}$, and strike the best possible deal with it. And if they do not get it, ${ }^{133}$ customers will turn to $\mathrm{R}$ who will give them $\mathrm{L}<\mathrm{PM}<\mathrm{H}$. In both scenarios, there will be an improving coalition as to the real conditions of the market, and the competitive process will be kept intact.

In the second state of the world, $\mathrm{R}$ do not know $\mathrm{L}$. There is imperfect information. In this variant, it is common-sensical to assume that $\mathrm{R}$ must randomly under or overestimate $\mathrm{L}$. The unconfident $\mathrm{R}$ will overestimate $\mathrm{L}\left(\mathrm{L}^{\prime}<\mathrm{L}\right)$. They will not enter the market. And the confident $\mathrm{R}$ will underestimate $\mathrm{L}(\mathrm{L}$ ' $>\mathrm{L})$. They will thus not compete against the real $\mathrm{L}$, but against a price they believe they can beat, and that is lower than $\mathrm{H}$. The confident $\mathrm{R}$ will again enter the market, and offer better coalitions to customers.

EDLIN and FARRELL's model of virtual limit pricing is thus fictional. Moreover, we are not convinced by the suggestion that it is superior to other liability standards, an in particular to outcome/output ones, because antitrust agencies will not wrestle with complex price-costs. This is indeed an incongruous argument, for with this definition, antitrust agencies are conducted to wrestle with ghost prices.

Their paper further seeks to bring conceptualization by advancing novel concepts such as "price patterns" in lieu of "price levels" or the idea that $\mathrm{M}$ can "move the goalposts" by threatening $\mathrm{R}$ to compete against lower prices to win customers, than those that prevail in the actual market. In fairness, one fails to see what this has to offer to the analysis, beyond sleek, eye-catching jargon.

EDLIN and FARRELL's paper makes a number of important points though. In particular, their paper usefully irons out the caricatured presentation that in a competitive process paradigm, economics shall no longer inform antitrust enforcement. The competitive process concept bodes very well with the policy trend that consists in applying a "more economic" approach in abuse cases (though the Guidance Paper was more "outcome" spirited). If Article 102 TFEU is ever approached as a prohibition on dominant firms to thwart the formation of improving coalitions between their rival and customers, then it will not dispense the EU agencies and courts from bringing economic evidence of such coalitions, and from measuring the various payoffs in question.

But the main obstacle to the acclimation of the "competitive process" as the goal of Article 102 TFEU does not lie in economists' difficulties to operationalize the notion of the competitive process. Rather, it is the language of the EU Treaties that displays repulse to the idea that the competitive process can be the goal of Article 102 TFEU. The prohibition of abuses couched in the Treaties focuses on conduct that imposes welfare decreasing outcomes on the market: "unfair purchase or selling prices or other unfair trading conditions"; "limiting production"; "applying dissimilar conditions to equivalent transactions", etc. Such abuses do not distort the competitive process. The Treaties' interest for the outcome of

\footnotetext{
${ }^{133}$ This is credible, because $\mathrm{M}$ does not know as well the new entrant and may believe that it cannot undercut $\mathrm{H}$.
} 
monopolists' conduct suggests that the founding fathers did not purport to protect the competitive process. This point was picked as early as 1970s by Professor JOLIET in a seminal essay, ${ }^{134}$ which demonstrated that the text of Article 102 TFEU covered only exploitative abuses, such as excessive prices or output restrictions. This was in contrast with the US antitrust context, where Congress did not prohibit high prices, but decided to ban restraints of trade or monopolization, thereby displaying more interest in the protection of the competitive process. Surely, the EU upper court expanded in Continental Can the notion of abuse to exclusionary conduct and repeatedly held that the list of abuses found in Article 102 TFEU was not exhaustive. But judicial precedent is reversible. And if we return to statutory language in search of the goals of EU antitrust law, Treaty support to the "competitive process" paradigm appears weak.

WILS is of a distinct opinion. In his view, the introduction in 2007 of a Protocol No 27 as Annex to the EU Treaties has refurbished the legal basis insufficiency that we just diagnosed. WILS asserts that "it is clear from Protocol No 27 on the internal market and competition, annexed to the Treaty of Lisbon, that the objective of Article 102 TFEU (and of the other EU competition rules) is a system of undistorted competition, as part of the internal market established by the EU". On this ground, WILS writes that the 2007 addition of Protocol no 27 to the Treaty marks a clear endorsement of the competitive process as a goal for EU antitrust law. ${ }^{135}$ WILS thus considers that the debate in the scholarship over the objective of Article 102 TFEU is largely irrelevant. ${ }^{136}$ And given the quasi-constitutional nature of the 2007 upgrade, WILS concludes that neither the Court of Justice, nor the Commission and Council have a say over the issue.

Can things be all that simple? Let us ignore for a minute the main weakness of the argument, and assume away that the notion of "system of undistorted competition" can be taken as a synonym of the "competitive process". WILS' point misreads the genesis of the Lisbon Treaty in relation to competition law. As most European readers know, Protocol No 27 has a convoluted legal history. In 2007 in Lisbon, the Heads of State decided to suppress Article 3, $\S 1, \mathrm{~g})$ from the EU Treaties, which stated that "the activities of the Community shall include [...] a system ensuring that competition in the internal market is not distorted". With this, the Heads of State sought to address the growing distrust in public opinion with free market policies - including antitrust - expressed in two failed referendums in France and the Netherlands. In a sort of legal quid pro quo, however, the Heads of State decided to keep a discrete reference to "undistorted competition" in a Protocol annexed to the Treaty. This Protocol has same legal value as the Treaty. But in an annexed Protocol, the status of competition policy is given less symbolical prominence than in the first articles of the Treaty.

The demotion of "undistorted competition" in a Protocol triggered a supernova of outcries in the antitrust industry. ${ }^{137}$ In Brussels, the talk of the town was that the Lisbon Treaty had downgraded the objective of undistorted competition in EU law.

\footnotetext{
${ }^{134}$ R. JOLIET, Monopolization and Abuse of a Dominant Position - A Comparative Study of the American and European Approaches to the Control of Economic Power, Collection scientifique de la faculté de droit de l'université de Liège, Faculté de droit, Université de Liège, Martinus Nijhoff, La Haye, 1970.

${ }^{135}$ WILS, supra note 5, pp.417. He also writes that the Treaties "clearly specify the objective of the EU competition rules". Unlike in the US, where the Sherman Act does not specify the objective of the antitrust rules, and where it is incumbent on the courts to define it, the situation would be radically different in the EU.

${ }^{136}$ Idem, at p. 16 : "Whatever views this or that economist or other person or many or most of them may have as to what the objective of Article 102 TFEU should be is irrelevant, unless a debate were to be opened on changing the EU Treaties."

${ }^{137}$ Including by the writer of this essay.
} 
In response to this, Michel PETITE, the former Director of the Legal Service made the following important rectification:

"As a matter of fact, competition is not currently one of the objectives of the European Community set out in Article 2 of the EC Treaty: the reference to "undistorted competition" appears only in Article 3 on the Community activities to be implemented to attain those objectives. Clearly, an objective that does not exist cannot be lost!" 138

In other words, under the pre-Lisbon Treaties, "undistorted competition" never was an objective of the EU. Article 2 of the Treaty, which is the constitutional provision that hosted the EU's objectives, made no single reference to undistorted competition. Consequently, no objective had been suppressed, weakened or modified, by virtue of the 2007 Lisbon Treaty modification.

The upshot of this analysis is that WILS cannot be right on the interpretation of Protocol no 27. The introduction of a Protocol seeking to make "undistorted competition" less obtrusive cannot, as he pretends, erect let alone create, an objective, a goal or purpose of undistorted competition in the EU legal order.

In addition, WILS' analysis is further riddled by two errors, known in logic as fallacies of unwarranted assumptions (implicit suppositions whose truth is either false or uncertain). First, Protocol No. 27 prescribes that "the internal market as set out in Article 3 of the Treaty on European Union includes a system ensuring that competition is not distorted". The text of Protocol No 27 talks of a "system" and not of an "objective" as WILS analogizes. And those words cannot be assumed to mean the same thing. At a conceptual level, a system can indeed have several objectives. And an objective can run on several systems.

A similar argument applies to the claim that Protocol No 27 protects the competitive process. The reference to the idea that "competition is not distorted" potentially encompasses outcome distortions as much as process distortions. And one cannot assume arbitrarily that the Heads of State had process in mind, when they surgically transferred Article $31 \mathrm{~g}$ ) in an Annex to the Treaties.

With all this, there is no strong economic and legal support to the proposition that the competitive process is the lynchpin of Article 102 TFEU. In particular, neither the language nor the spirit of the Treaty provide clear backing to this argument.

\section{B. CONSUMER CHOICE}

A second possible non-outcome foundation for Article 102 TFEU is "consumer choice". In Intel, the Court observes on several occasions that Intel restricted its OEM's "freedom of choice" of supplier. It is thus worth exploring if "consumer choice" can be the raison d'être of Article 102 TFEU.

\section{State of the Art}

The proposition that consumer choice should be hailed as a goal of antitrust law is not new. It has gained momentum in the past 20 years, with the growing influence of behavioural economics in public policy. Neil AVERITT and Robert LANDE were amongst the firsts to vindicate its introduction in US antitrust policy, as an alternative to the dominant price and

\footnotetext{
${ }^{138}$ See M. PETITE, EU commitment to competition policy is unchanged, Financial Times, 27 June 2007.
} 
efficiency standards. ${ }^{139}$ According to AVERITT and LANDE, the antitrust prohibitions should "seek to eliminate practices which artificially restrict the choices the free market would otherwise have provided". ${ }^{140}$

AVERITT and LANDE have advanced two considerations to sell a shift to consumer choice standard. ${ }^{141}$ First, the consumer choice standard is more inclusive than others. In particular, a consumer choice standard would better apprehend non-price competition dynamics than a price or efficiency standard. ${ }^{142}$ Under a price standard, a wide array of anticompetitive practices evade the kill switch of the antitrust prohibitions (for instance, an agreement to limit advertisement). Those are captured by a consumer choice standard, thereby limiting type II errors. ${ }^{143}$ Second, the consumer choice standard has a series of "administrative advantages": it facilitates convergence on the international antitrust scene; it creates synergies with other branches of the law such as consumer protection; and it explains simply to the public opinion why a system of competitive capitalism is good for consumers. ${ }^{144}$

In Europe, the debate on the acceptability of consumer choice as a goal of antitrust is arguably far more mature, and less controversial, than in the US. ${ }^{145}$ AVERITT and LANDE consider that "some EU statements on competition policy are already framed in terms very similar to our proposed choice approach". Professor NIHOUL goes even further. In his view, the law on abuse would already be based on consumer choice. In a comprehensive paper, NIHOUL sustains that consumer choice is present "as a mechanism, in all Article 102 TFEU cases". ${ }^{146}$

${ }^{139}$ N. W. AVERITT and R. H. LANDE, "Consumer Sovereignty: A unified theory of Antitrust and Consumer Protection Law" (spring 1997), 65 Antitrust L.J. 713; "Consumer Choice: The Practical Reason for Both Antitrust and Consumer Protection Law", 10 Loyola Consumer Law Review 1 (1998),

${ }^{140}$ Idem (1998 paper). At a stylized level, the consumer choice standard prohibits all activity that "unreasonably restricts the totality of price and nonprice choices that would otherwise have been available". In their view, markets must offer consumers a range of options. And consumers must be able to select freely amongst those options. However, by virtue of market imperfections such as search costs, faulty information, time lags, sunk costs, etc. the menu of options available to consumers can be reduced. AVERITT and LANDE explain for example that predatory pricing can only succeed if there is a flaw in the capital market, "for without such a flaw the victim would be able to secure a loan and ride out the period of below cost pricing". Idem, supra note 140 at p. 51. Such statements were, however, profoundly confusing. In AVERITT and LANDE's first paper (and in the example given), it seemed that AVERITT and LANDE suggested attaching liability to dominant firms for external market imperfections. Moreover, their initial paper also suggested that absent such endogenous market imperfections, firms could freely engage into conduct that would otherwise have been deemed abusive in conventional antitrust standards. In subsequent papers, AVERITT and LANDE refined their proposal.

${ }^{141}$ AVERITT and LANDE have however recognized a variety of implementation issues. They concede that "it is somewhat more complex than the alternatives, and it is less tied to objective metrics, such as prices and elasticities" ("Using the "Consumer Choice" Approach to Antitrust Law, 74, ANTITRUST L.J. 175, 199-216 (2007), p. 237). For example, they admit that not all reductions of choice, but only significant decreases ought to be pursued (for instance, not a reduction from 10 to 9 products, but maybe a reduction from 2 to 1 ). But they steer clear of providing useful benchmarks to distinguish when choice options are optimal and not. Similarly, AVERITT and LANDE explain that the consumer choice standard brings little added value in commoditized products where the sole competitive parameter is price.

${ }^{142}$ On markets where price competition is insignificant, where the restriction is not on price (an agreement to limit advertising) or where firms compete through product development.

${ }^{143}$ AVERITT and LANDE, supra note 140 at p. 248: noting that "particular cases will be decided more correctly".

144 Idem, at 179.

${ }^{145}$ In our own view, the recognition of consumer choice never went beyond sweeping policy statements and contextual judicial affirmations. However, consumer choice never seemed to be approached as a possible liability standard, as proposed by AVERITT and LANDE. Things, however, changed a little in the 2010s, when a group of scholars led by Professor NIHOUL sought to revisit the EU case-law to the effect that the positive liability standard is consumer choice.

${ }^{146}$ P. L. NIHOUL, "Freedom of Choice - The Emergence of a Powerful Concept in European Competition Law", http://papers.ssrn.com/sol3/papers.cfm?abstract_id=2077694. 
His analysis is based on a thorough lexical review of the Article 102 TFEU case-law, as well as of recent high profile cases, most notably France Telecom, Microsoft, and the Commission decision in Intel. ${ }^{147}$

With this background, is it true that consumer choice is the positive goal of Article 102 TFEU - as argued by NIHOUL and others - and what does Intel tell us about it? Unlike in the previous section, we start with a review of the legal arguments, and we then discuss some economic considerations.

\section{Legal Assessment}

The Treaty wording does not talk of consumer choice. But Article 102 b) TFEU makes a discrete reference to conduct that limits production "to the prejudice of consumers". Unlike for the competitive process, there seems to be less Treaty obstacles to the accommodation of "consumer choice" as the goal of Article 102 TFEU.

However, it is the case-law that defeats the proposition that consumer choice is the goal of Article 102 TFEU. It is certainly true that in most EU judgments, and especially in Intel, consumer choice was relevant in the analysis. But it is equally true that consumer choice was often - if not always - accompanied by a complementary concern: that by removing consumer choice, the dominant firm had restricted rivals' market access. In other words, restrictions on consumer choice have only been a problem in the case-law to the extent that they gave rise to an exclusionary effect. ${ }^{148}$ This means that consumer choice is not an end in itself. At best, it is a contingent or ancillary paradigm. ${ }^{149}$

Moreover, the idea that consumer choice may have been the dominant paradigm in the Article 102 TFEU case-law considered in NIHOUL's paper was disavowed in 2012 by the upper EU court. In Post Danmark, a case concerning limit pricing practices, the Court affirmed that:

"not every exclusionary effect is necessarily detrimental to competition. Competition on the merits may, by definition, lead to the departure from the market or the marginalisation of competitors that are less efficient and so less attractive to consumers from the point of view of, among other things, price, choice, quality or innovation". ${ }^{150}$

With this statement, the Court implicitly ruled that consumers can end up with a single supplier, which marks the antithesis of consumer choice. ${ }^{151}$ In a single supplier scenario, buyers have no ability to "switch", which constitutes the defining feature of "consumer choice". More fundamentally, Post Danmark embraces a Darwinian vision of economic competition which is conceptually irreconcilable with the consumer choice standard.

\section{Economic Assessment}

\footnotetext{
${ }^{147}$ Idem. NIHOUL writes that it has been "given a relatively prominent status in the application of Article 102 TFEU since the beginning of European integration", supra note 2, at p.11.

${ }^{148}$ Conversely, dominant firms can lawfully restrict consumer choice, as long as this inflicts no harm to competitors.

149 This is absolutely striking when one reviews the section of the Intel judgment where the court sets out the legal framework. The restriction of choice does not occupy a prominent place here. It appears only on two occasions only at paragraph 130-131 and at paragraph 169. And it is systematically followed by the proposition that by removing supplier choice, the dominant firm makes rivals market access "more difficult". See also paragraph 1031 which shows this too, when the Court affirms that "the exclusivity rebates granted to NEC were actually capable of restricting NEC's freedom of choice and thus of making access to the market at least more difficult for AMD". By the same token, reference to choice is merely contingent.

${ }^{150}$ Post Danmark judgment, supra note 51, at paragraph 22.

${ }^{151}$ And it admits that the dominant Danish postal operator could exclude less efficient rivals through limit pricing.
} 
We come now to the discussion of the economics of consumer choice. In our view, basic monopoly theory trumps the recognition of consumer choice as a possible goal for Article 102 TFEU. In a market subject to a monopoly, the sole price level likely to improve consumer choice is the price level that triggers entry. But economic theory explains that a true monopolist can charge the monopoly price without attracting competitive entry. In the standard monopoly model, the sole price level that can thus draw new firms in the market and ameliorate consumer choice - is a "supra monopoly" price. ${ }^{152}$ This, in itself, reveals the extravagant remedial implications of consumer choice as a policy goal. Under a consumer choice paradigm, dominant firms should be required to keep prices above the monopoly level (or as high as possible), for this would stimulate entry and choice. And they should be barred from tariffing below for this would discourage entry and choice. This, clearly, cannot be the law.

But there are other reasons against the recognition of consumer choice as the objective of Article 102 TFEU. Amongst them, a crucial objection is that a consumer choice standard risks handicapping agencies in their fight against sophisticated exclusionary practices, like predatory marketing or product innovation strategies (assuming they exist). In a much discussed paper published in the early 1980s, Janus ORDOVER and Robert WILLIG established that anticompetitive predation can occur in the form of "genuine innovations-new products that in some ways are superior to existing products in the eyes of both engineers and consumers". ${ }^{153}$ In a consumer choice model where antitrust is to "protect any type of choice that is of practical importance to consumers", should there be blanket Article 102 TFEU immunity for such practices? Is this what the consumer choice advocates have in mind when they argue that their paradigm is more inclusive?

The traps of a consumer choice standard in Article 102 TFEU can be further envisioned in relation to commoditized products. Take the example of a patent-expiring drug. Under a consumer choice standard, the patent holder's measures to delay or discourage generic entry would be complex to deem abusive. In most circumstances, the business model of generic firms consists in duplicating the patent holder's drugs. This does not deliver a significant improvement in the choice provided to consumers. Surely, consumers face a larger price menu following generic entry. But in this case the consumer choice doctrine is useless. Agencies and complainants before courts seeking a finding of abuse only need to show that generic entry yields reduced prices, which improves consumer welfare. Put differently, the detour by the consumer choice route brings little added value to an outcome paradigm focused on consumer welfare.

Beyond those considerations, the economic foundations of consumer choice remain probably too shaky at this stage to be fit for antitrust embedment. ${ }^{154}$ In the modern economic literature behavioralists have - perhaps counter intentionally? - adjudicated against consumer choice as a possible antitrust goal, by showing that consumers make poor choices due to physiological,

${ }^{152}$ For use the expression, see E. ELHAUGE, "Tying, Bundled Discounts, and the Death of the Single Monopoly Profit Theory", 123 HARV. L. REV. (Dec. 2009).

${ }^{153}$ A dominant firm may introduce a new product and service with a view to forcing rivals into obsolescence. Their paper advanced a series of illustrations, in particular from the software industry where new releases and upgrades are frequent.

${ }^{154}$ For instance, in social sciences, an emerging trend of studies alerts that the constant production of choice, alternatives, and menus by the economic system leads individuals to primitively accumulate goods and services, and in turn, to overconsume. Whilst this is a very important philosophical debate that goes beyond the ambition of this essay, it is certainly interesting to consider whether the embedment of "consumer choice" in antitrust policy would inaptly contribute to the "treadmill of production" described by SCHNAIBERG in 1980 and lead to welfare decreasing behavior in the abstract. 
cognitive and psychological limitations. ${ }^{155}$ In this context, why should antitrust regimes protect free choice by all means, if choice is so defective? In the alternative, why should antitrust correct deficient consumer choice, if all Member States of the EU have harmonized rules on unfair business to consumer (B2C) commercial practices and on consumer rights? ${ }^{156}$ The efficacy and legitimacy of antitrust intrusion in areas subject to dedicated legislation remains to be proven. Surely, there is a case for antitrust, when dominant firms fiddle with consumer choice to harm competitors or to usurp more consumer surplus than they could otherwise do. ${ }^{157}$ But this is not terra incognita for antitrust law. Cases like Microsoft I and $I I$, where the dominant software producer exploited consumer inertia to trounce competing media players and Internet browsers, amply show this. ${ }^{158}$

\section{RAISING RIVALS' COSTS}

The idea that a dominant firms abuses by making rivals' access "more difficult" can finally be tied to the raising rivals' costs theory (hereafter, "RRC theory"). The genesis of RRC theory can be traced to a conference hosted by the US Federal Trade Commission ("TFC") in June 1980. The conference centred on how to approach non price predation in monopolization cases following US v E.I. du Pont de Nemours \& Co. ${ }^{159}$ In its famous 1957 ruling, the US Supreme Court had restricted the availability of non-price predation claims under Section II of the Sherman Act.

The conference failed to come up with a grand unifying answer. But it prompted more research. In 1983, Steven SALOP and David SCHEFFMAN - then economist with the FTC - published an article with the American Economic Review entitled "Raising Rivals' Costs", which paved the way to the formation of a rich body of literature often referred to as the "RRC papers". ${ }^{160}$ In antitrust scholarship, RRC theory was vigorously criticized. Some went as far as to call it a "fable". ${ }^{161}$ Its influence on antitrust enforcement remained marginal until the mid-1990s, when it gained some traction with the rise of Post Chicago economics.

The RRC framework is not strictly about "making access to the market more difficult for a competitor" as aired out in Intel. It is about something close: making rival production more difficult through inflated costs. RRC theory pretends that a dominant firm can induce rivals to exit, not only by sacrificing its own profits as in the classic predatory pricing scenario, but

\footnotetext{
${ }^{155}$ Individuals do not always behave rationally, seeking to maximize profits, as industrial theorists posit. They cannot - and do not - collect, process and analyze all the information necessary to make cost-benefit analysis. Individuals exhibit features such as "bounded rationality", "bounded willpower", and "bounded self-interest". The first of these terms refers to the fact that people have "cognitive quirks that prevent them from processing information rationally"; the second that they exhibit weakness of will; and the last refers to the fact that people "sometimes act out of motives that do not seem explicable by self-interest". See R. POSNER, "Rational Choice, Behavioral Economics, and the Law", Stanford Law Review, Vol. 50, No 5, 1998, 1551. See Posner, R. Rational Choice, Behavioral Economics, and the Law. Stanford Law Review, Vol. 50, No 5, 1998, 1551; M. STUCKE, "Money, Is That What I Want?: Competition Policy and the Role of Behavioral Economics", Santa Clara Law Review, 50, 2010, p. 101.

${ }^{156}$ Directive 2005/29/EC, OJ L 149, 11.6.2005, p. 22; Directive 2011/83/EU, OJ L 304/64, p. 64.

${ }^{157}$ See P. MARSDEN, who advances the idea that antitrust law should ensure that firms do not manipulate the "exercise of choice" (JECLAP, "Exercising choice" http://m.jeclap.oxfordjournals.org/content/early/2014/10/15/jeclap.lpu095, accessed 11 May 2015)

${ }^{158}$ N. PETIT and N. NEYRINCK, "Back to Microsoft I and II: Tying and the Art of Secret Magic", Journal of European Competition Law \& Practice, 2011, Vol. 2, No. 2, p. 117.

${ }^{159}$ United States v. E. I. du Pont de Nemours \& Co., 353 U.S. 586 (1957).

${ }^{160}$ S. SALOP and D. SCHEFFMAN, 'Raising rivals' costs', American Economic Review 73, 267-71.

${ }^{161}$ See J. E. LOPATKA and P. E. GODEK, "Another Look at Alcoa: Raising Rivals' Costs Does Not Improve the View", Journal of Law and Economics, Vol. 35, No. 2 (Oct., 1992), pp. 311-329, as reprinted in D. SPULBER (Ed.), Famous Fables of Economics: Myths of Market Failures, Wiley, 2001.
} 
also by imposing cost increases on rivals with the purpose or effect of raising their prices (or reducing their output). The underlying mechanism is simple. A dominant firm can influence the supply curve of an elastic fringe firm by raising its costs. With inflated costs, the reservation price at which the fringe firm will be ready to serve customers will increase, and it will produce less (it will chose a price higher on its supply curve). The demand left unsatisfied by the fringe supplier will then turn to the dominant firm, whose residual demand curve will shift out. And the dominant firm can use the increased price of the fringe firm as a sort of price umbrella.

Importantly, the dominant firm does not need to deprive rivals of profitability. According to RRC theory, there can be antitrust liability even if the competitor remains profitable. As SALOP explains "successful RCC does not require the exit of rivals or even the permanent reduction in competitors' production capacity. If the marginal costs of established competitors are raised, those rivals will have the incentive to raise prices and reduce output, even if they remain viable". ${ }^{162}$ This appears in contrast with the outcome-based tests previously discussed, where the emphasis is on the economic unviability of a hypothetically as efficient rival.

Moreover, whilst RRC theory certainly finds antitrust liability if the cost increase only targets the rival (for instance, the dominant firm convinces the Government to introduce a ban of certain rivals' products), it also applies when the "cost increase imposed on rivals has a similar effect on the instigator" (for instance, an advertisement campaign). In those cases, the dominant firm may have an incentive to increase in its own costs, "if it can raise the market price at the current level of output by more than [it] raises its average costs". ${ }^{163}$

It is not our purpose here to discuss at length the pros and cons of RRC theory. But we would like to recall several important points. First, whilst RRC theory certainly looks "process" oriented at the formulation level - and therefore Intel-compatible - it remains deeply "outcome"-loaded at the testing level. SALOP and SCHEFFMAN recall the three necessary conditions for a finding of antitrust liability: profitability to the dominant firm, competitor injury, and consumer welfare reduction. ${ }^{164}$ With distinct words, KRATTENMAKER and SALOP make a similar point: "a firm that raises its rival's costs has not necessarily gained anything. It may have harmed one or more of its competitors, but has it harmed competition?". ${ }^{165}$ In spite of appearances, RRC theory thus fares poorly with the processinspired wording of Intel. In contrast, it is more attune to the outcome based-spirit of the Treaty wording and of the Guidance Paper.

Second, RRC theory is based on the textbook economic model of dominant firm price leadership. In this model, the dominant firm competes with a fringe of rivals. A constant assumption of the model - that is often not explicated in the RRC policy papers - is that the

\footnotetext{
${ }^{162}$ S SALOP, Exclusionary Conduct, Effect on Consumers, and the Flawed Profit-Sacrifice Standard, 73 Antitrust L.J. 311-374 (2006), at p.143.

${ }^{163}$ S. SALOP and D. SCHEFFMAN, supra note 161 at p.376.

${ }^{164}$ S. SALOP and D. SCHEFFMAN, supra note 161 at p.270. It is often forgotten by proponents of this theory that both dominant firm and the fringe rival may lawfully maintain higher industry profits, if there are barriers to entry. In this scenario, there is no cause for antitrust liability absent competitor harm. Similarly, RRC theory would not apply in support of antitrust liability if, as observed by SALOP and SCHEFFMAN "demand and supply elasticity are increased sufficiently to cause price to fall enough to offset the welfare losses from the higher costs".

${ }^{165}$ Idem. In their view, a necessity is to show that, having harmed rivals costs, the dominant firm has gained power over price. The mere effect on productive inefficiency shall not lead to impose antitrust liability, because in general "firms have no incentives to impose production inefficiencies on their rivals [...] unless they also can achieve power over price".
} 
dominant firm has lower costs than smaller rivals. ${ }^{166}$ More specifically, RRC theory takes the fringe firms' supply curve as a proxy for rivals' incremental costs, and this curve is systematically above the dominant firm's average costs curve. This has important implications for EU antitrust law. To start, the transplantation of the RRC paradigm in Article 102 TFEU law would require the explicit admission that abuse occurs when conduct harms less efficient rivals. In positive law, this is more the exception than the rule, though the Guidance Paper recognizes this possibility. ${ }^{167}$ In turn, RRC theory does not clearly explain the consequences to be attached to conduct that targets as (or more) efficient rivals. Should such cases be dismissed, if the dominant firm can prove that rivals are equally (or more) efficient? Or should they be pursued, because conduct that harms equally (or more efficient) rivals necessarily harms (in equilibrium) less efficient potential competitors?

In addition, the RRC framework is not easy to reconcile with the European theory of liability that rivals" "access to the market" is abusively made "more difficult" by the dominant firm. Indeed, in the RRC model, rivals' access to the market is presumptively made "more difficult" by the wealth of efficiencies associated with the dominant position - which is lawful - and by the small-scale inefficiencies of the fringe firms. The upshot of this is that the "more difficult" position of rivals is not exogenously caused by the dominant firm conduct, but already pre-exists endogenously in the model. Under an RRC standard, insuperable causation problems would thus come to the surface, when trying to distinguish the contribution of the dominant position from that of the impugned abuse to the "more difficult" market access of rivals.

Third, and possibly more importantly, the application of the RRC model is liable to be voracious in terms of enforcement resources, a point to which agencies are likely to be very sensible as aptly noted by WILS. ${ }^{168}$ The concrete implementation of a RRC paradigm will consume a vast amount of quantitative economic data, in particular in relation to supply and demand side elasticities, costs, etc. ${ }^{169}$ In addition, the RRC framework commands to resolve complex methodological questions at early stages of the antitrust investigation. In terms of enforcement costs, the RRC paradigm may thus prove almost as expensive as the outcome paradigm allegedly derided in Intel.

\section{CONCLUSION}

The positive law conclusion from all the above is that Intel sets a modified per se prohibition standard for exclusivity rebates that strays from Hoffmann-La Roche. This prohibition applies to exclusivity options that operate through leveraging. In contrast, non-leveraging rebates are subject to a rule of reason standard. Moreover, the Intel court's judgment does not nullify the

\footnotetext{
${ }^{166}$ S. J. RASSENTI and B. J. WILSON, "How Applicable is the Dominant Firm Model of Price Leadership", Experimental Economics, 7; 271-288 (2003); M. UTTON, Market Dominance and Antitrust Policy, Edward Elgar Publishing, 2003 at pp.63-65. See also, M. B. COATE and A. N. KLEIT, "Exclusion, collusion and confusion: the Limits of Raising Rivals' Costs, FTC Bureau of Economics Working Paper No. 179, 1990, for a formal analysis, that comes to the conclusion that cost asymmetries are required to apply the RRC model. http://www.ftc.gov/sites/default/files/documents/reports/exclusion-collusion-and-confusion-limits-raising-rivalscost/wp179.pdf

${ }^{167}$ Guidance Paper, supra note 6 at paragraph 24.

${ }^{168} \mathrm{~W}$. WILS, supra note 5.

169 S. SALOP and D. SCHEFFMAN, supra note __ at p.255. For instance, in their 1986 paper, KRATTENMAKER and SALOP insist on measurement issues, noting that in relation to input costs, "the increase in the cost of that input must be significant, in magnitude and duration, as well". See T. G. KRATTENMAKER and S. C. SALOP, "Anticompetitive Exclusion: Raising Rivals' Costs To Achieve Power over Price”, 96 Yale L.J. 209 1986-1987, at p.255.
} 
substantive, "more economic" framework set out in the Commission's Guidance Paper, and could not possibly so, given the lack of formal applicability of this official document in the case. On the contrary, the Intel court affirms the justifiability defense introduced in this document, and subsequently confirmed by the CJEU in Post Danmark. Finally, the case-law analyzis provided by the Intel court in support of its reasoning is on the whole very weak and riddled with disconcerting inconsistencies. It may not be strong enough to carry the case.

Assuming that it is right to read in Intel the consecration of a non-outcome (or non-welfarist) goal for Article 102 TFEU, the prospective law conclusion from our analysis is that none of the alternative standards, ie process, consumer choice, or RRC advanced in the literature seem apt to become the objective of Article 102 TFEU.

With this background, let us close this essay with a reference to Nobel Prize economist Friedrich HAYEK, who has often been cited in the early Intel papers. ${ }^{170}$ If HAYEK was still alive, he would plausibly commend EU antitrust lawyers. The competition for ideas that has arisen in academic journals since Intel is a lively illustration of his 1978 theory of Competition as a Discovery Procedure. ${ }^{171}$ Most likely, intellectual competition will assist the CJEU in discovering the right legal solution, and bring to a closing outcome this important positive and prospective debate.

Also, if Friedrich HAYEK was still with us, he would certainly invite antitrust lawyers to rediscover his previous 1946 article The Meaning of Competition. ${ }^{172}$ This paper, which has been absent from the early Intel scholarship, articulates a conception of market competition that both philosophically and semantically contains the efficiency, consumer harm, and dynamic competition ingredients found in the Commission's "more economic", effects-based approach to Article 102 TFEU (advocated in the Guidance Paper, and endorsed by the CJEU in Post Danmark). Let us quote HAYEK:

"Much more serious than the fact that prices may not correspond to marginal cost is the fact that, with an entrenched monopoly, costs are likely to be much higher than necessary. A monopoly based on superior efficiency, on the other hand, does comparatively little harm so long as it is assured that it will disappear as soon as anyone else becomes more efficient in providing satisfaction to the consumers (emphasis added)". 173

\footnotetext{
${ }^{170}$ WILS, supra note 5 ; REY and VENIT, supra note 2.

${ }^{171}$ F. HAYEK, "Competition as a Discovery Procedurel, in New Studies in Philosophy, Politics, Economics and the History of Ideas (University of Chicago Press, 1978).

${ }^{172}$ F. HAYEK, "The Meaning of Competition", in Individualism and Economic Order, (Chicago: Chicago University Press, 1948); English translation available at http://mises.org/library/meaning-competition (accessed 11 May 2015).

173 Idem.
} 